\title{
Aproximación al pensamiento teológico de Epicteto
}

\author{
JAVIER ANTOLÍN SÁNCHEZ
}

Resumen: Epicteto es un pensador de la escuela tardía estoica, el llamado estoicismo romano y vivió del año 50 al 135 . Su pensamiento se caracteriza por la gran impronta teológica, pues constantemente se refiere a Dios como el fundamento de su filosofía. Aunque Epicteto es fiel a la tradición materialista estoica, en muchas de las referencias a Dios, aunque no rompe con el pensamiento clásico, sobresale por darle un toque personalista a Dios, que le aproxima bastante al cristianismo. Después de una breve reseña de su vida e influencias filosóficas, presentamos su pensamiento teológico centrándonos sobre todo en sus Disertaciones, y podemos concluir diciendo que Epicteto, más que a ningún otro estoico, se le podría aplicar el título de teólogo, pues la referencia a lo divino es central para su filosofía.

Palabras claves: Epicteto, estoicismo, ética estoica, filosofía como forma de vida, panteísmo, teísmo, teología estoica.

Abstract: Epictetus is a thinker of the late Stoic school, the so-called Roman Stoicism, and lived from the year 50 to 135 . His thought is characterized by great theological imprint, since he constantly refers to God as the foundation of his philosophy. Although Epictetus is faithful to the stoic materialistic tradition, in many of the references to God, although he does not break with classical thought, he stands out for giving a personalistic touch to God, which is very close to Christianity. After a brief review of his life and philosophical influences, we present his theological thought focusing above all on his Dissertations, and we can conclude by saying that Epictetus, more than any other Stoic, could apply the title of theologian, since the reference to the divine is central to his philosophy. 
Key Words: Epictetus, Pantheism, Philosophy as way of life, stoic theology, stoic ethics, stoicism, Theism.

\section{INTRODUCCIÓN}

Epicteto que floreció a finales del siglo primero es, juntamente con Séneca y Marco Aurelio, una de las tres figuras de la Estoa tardía que se desarrolla en Roma y se suele llamar estoicismo romano. Entre los profesores estoicos, -ya que tanto Séneca como Marco Aurelio no fueron maestros de filosofía- es el único que podemos leer más extensamente, ya que el pensamiento de los primeros estoicos y los escritos de la Estoa antigua han sobrevivido solamente en fragmentos. Y además es el profesor estoico de filosofía del que conservamos su obra de una forma continuada.

Dentro del estoicismo romano no aparece ninguna doctrina nueva, sino que representa una continuidad con lo anterior, pero se suele desentender de los problemas teóricos y se centra en la dimensión ético-práctica ${ }^{1}$. Epicteto fue un profesor reconocido de la filosofía estoica, por lo que daba importancia a la fundamentación teórica, ya que, para él, el comportamiento correcto es el resultado de la lógica en los argumentos racionales, pues de los errores lógicos se derivan errores éticos. Pero hemos de decir también que su filosofía, eminentemente ética, está validada por su propia experiencia.

Epicteto heredó las líneas principales del pensamiento de sus predecesores estoicos, y no sintió la necesidad de discrepar de lo que consideraba sólidamente fundamentado en hechos y argumentos. A este respecto, fue un seguidor típico de la escuela filosófica de la antigüedad tardía, viviendo en un tiempo en que los filósofos se veían a sí mismos como continuadores de unas tradiciones de larga duración ${ }^{2}$.

${ }^{1}$ GILL, Christopher, "The School in the Roman Imperial Period," en The Cambridge Companion to the Stoics, Inwood, Brad, (ed.) Cambridge University Press, Cambridge 2006, 33 y 40. El estoicismo fue el movimiento filosófico dominante de este período y se dejó empapar de la cultura grecorromana. Un área en la que la filosofía estoica de este período es creativa es el de la ética práctica o aplicada.

${ }^{2}$ Long, A. A., Epictetus. A Stoic and Socratic Guide Life. Clarendon Press, Oxford \& New York, 2004, 31 y 17. Epicteto utiliza el estoicismo selectiva y creativamente. Una de las razones es por sus inclinaciones socráticas, algo que no ha sido suficientemente apreciado, pero también por su propia interpretación de lo que significaba ser filósofo y profesor estoico. 
La clave de la felicidad, sugiere Epicteto, es analizar continuamente nuestra experiencia del mundo en términos de esta división entre lo que "depende de nosotros" y lo que "no depende de nosotros" (1.1; 1.22.9-10). Argumenta que casi toda la miseria humana es consecuencia de que las personas no comprenden la naturaleza y el significado de esta división, de asumir que tienen el control de cosas que de hecho no tienen, y de basar su felicidad en cosas externas que "no dependen de nosotros" y al hacerlo así, se vuelven altamente vulnerables a las vicisitudes de la fortuna. En cambio, debemos basar nuestra felicidad en las cosas que "dependen de nosotros", aquellas cosas que nunca nos pueden quitar. Si hacemos eso, nuestra felicidad será literalmente invulnerable ${ }^{3}$.

Epicteto, más que un filósofo, es un moralista y, como ya decía Pohlenz $z^{4}$, un hombre volcado más a la práctica que a la teoría. El enfoque de los estoicos antiguos es mucho más teórico que el de Epicteto. Aunque Epicteto reconoce la clásica división tripartita estoica de la filosofía en Física, Lógica y Ética, bien porque no mencionara la Física en sus lecciones, bien porque

${ }^{3}$ Sellars, John, Stoicism, Acumen, Durham 2010, 17. Long, A., Epictetus, 1. La felicidad y una vida digna de elogio requieren que controlemos nuestras mentes en todo momento, pues ellas son las responsables de la bondad o maldad que experimentamos y no algo externo o material. Todo lo que nos afecta para bien o para mal depende de nuestros propios juicios y de cómo respondemos a las circunstancias que nos suceden. GiLl, "The School," 48. De ahí la importancia de moldear nuestra vida en torno a la búsqueda de la virtud (que es, en principio, lo que depende de nosotros) en lugar de tratar de obtener las cosas "preferibles" (que no dependen de nosotros). НАDOT, Pierre, La ciudadela interior. Introducción a las Meditaciones de Marco Aurelio, Alpha Decay, Barcelona 2013, 168. De nosotros dependen los actos de nuestra alma, porque podemos escogerlos libremente: podemos juzgar o no juzgar, juzgar de tal manera o tal otra, podemos desear o no desear, querer o no querer. Por el contrario, lo que no depende de nosotros (Epicteto enumera: nuestro cuerpo, los honores, las riquezas, los altos cargos) es todo lo que depende del curso general de la naturaleza. Nuestro cuerpo: es cierto que podemos moverlo, pero no somos completamente dueños de él: el nacimiento, la muerte, la enfermedad, los movimientos involuntarios, las sensaciones de placer o de dolor escapan totalmente a nuestra voluntad. El estoico delimita, pues, su centro de autonomía: el alma por oposición al cuerpo, y el principio director (hegemonikon) por oposición al resto del alma. Y en este principio director se sitúan la libertad y el verdadero yo. Sólo ahí cabe situar el bien moral y el mal moral, puesto que el bien o el mal no pueden sino ser voluntarios. Ya sabemos el axioma fundamental del estoicismo: sólo hay felicidad en el bien moral, en la virtud; no hay desgracia más que en el mal moral, en la falta y el vicio.

${ }^{4}$ Pohlenz, M., Die Stoa. Geschichte einer geistigen Bewegung, 2 vols., Gotinga 1949. 
fuera un tema que no despertara suficiente interés de Arriano cuando ordena las Disertaciones ${ }^{5}$, el caso es que no encontramos ni un solo capítulo dedicado a ella y muy pocos dedicados en exclusiva a la Lógica (1.7). Lo que Epicteto nos presenta en sus Disertaciones es una colección de sugerencias prácticas, de comportamientos acordes con los principios estoicos-que aparecen explicados repetidamente- $\mathrm{y}$ tendentes a ofrecer a sus discípulos un camino adecuado para alcanzar la felicidad personal.

Lo que sí podemos constatar es que la filosofía de Epicteto ha tenido una gran influencia a lo largo de la historia ${ }^{6}$. Una de las primeras influencias es en Marco Aurelio, pues en sus Meditaciones I, 7 nos dice que debe a su maestro Junio Rústico el entregarle una copia de los escritos de Epicteto. Una de las razones para la gran influencia de Epicteto es que hizo el estoicismo accesible a un público más amplio, tanto en su propio tiempo como después. Epicteto no discute detalles de cosmología ni lógica, sino que le preocupa la cuestión de cómo podemos mejorar nuestras vidas. Además, escribió en un estilo atractivo y utilizó ejemplos extraídos de la vida real. Sus discursos tenían el objetivo de ayudar y aconsejar a los discípulos en su escuela. La filosofía en sí misma juega un papel aún mayor en su pensamiento de lo que era habitual en la antigüedad; mucho de lo que tiene que decir está relacionado con el método filosófico, la naturaleza de la educación filosófica, la vocación del filósofo, y la filosofía como forma de vida. Por lo que se le puede ver como un portavoz, no solo para el estoicismo, sino también para la filosofía en general, y esto puede explicar por qué de su pensamiento se apropiaron los filósofos de otras escuelas, incluidos los platónicos y los cristianos ${ }^{7}$.

Epicteto ha sido mal entendido por sus referencias teológicas, que se encuentran en todos los lugares, por eso ha sido leído consciente o inconscientemente a la luz del cristianismo. No hay razón para pensar que los cristianos o los textos cristianos le hayan influido directamente, aunque es posible pensar que Epicteto hubiera conocido o se hubiese encontrado

${ }^{5}$ Epicteto, Disertaciones por Arriano (=BCG 185), Traducción y notas Paloma Ortiz García, Gredos, Madrid 1993. En general, seguiré la traducción de esta edición.

${ }^{6}$ LoNG, A. A., Epictetus, 259. Su filosofía práctica ha tenido y tiene seguidores y simpatizantes a lo largo de todos los tiempos. Su seriedad moral y sus agudas observaciones trascienden la historia.

${ }^{7}$ Mason, S. Andrew and Scaltsas, Theodor., (eds.) The Philosophy of Epictetus, Oxford University Press, Oxford \& New York 2007,2-3. 
con los cristianos cuando era niño en Hierápolis, pues según la carta a los Colosenses 4,13 había misioneros cristianos allí y según Tito 3, 12 Pablo pasó algún tiempo en Nicópolis ${ }^{8}$ (2.9.21 y 4.7.6).

Epicteto no desdeña las prácticas religiosas tradicionales, sino que se centra en la única forma segura para evitar caer en la superstición: la postura correcta del filósofo. En contraste con sus contemporáneos, que tenían intereses en la interpretación de los sueños, magia y prácticas ocultas, su mentalidad es racionalista y apegada a la tierra, aunque habla de Dios en un tono que trasmite fe y experiencia personal, así como piedad socrática y estoica. Epicteto considera, como han creído otros filósofos antes que él, que los seres humanos nacen con todo lo que necesitan, en términos de capacidades básicas para comprender el mundo y que los impedimentos para vivir bien pueden ser corregidos o, al menos, mejorados, por una combinación de las doctrinas rectas y una autodisciplina constante 9 .

El estoicismo como filosofía ampliamente enseñada y vivida sobrevivió probablemente a Epicteto no más de 100 años. En esta época, aunque se reinterpretaban las escuelas filosóficas griegas, la primacía la llevaba el cristianismo. La actitud oficial de la iglesia primitiva hacia la filosofía griega fue de rechazo, pero podemos ver trazos del estoicismo en las cartas de san Pablo y en el Nuevo Testamento ${ }^{10}$, y, algunos pensadores cristianos, especialmente los alejandrinos, Clemente y Orígenes se apropiaron mucho de él, particularmente en el campo de la ética. En el período de los años 200 al 600 el nombre de Epicteto aparece con la frecuencia suficiente para mostrar que los cristianos influyentes lo estimaron como un pagano virtuoso ${ }^{11}$. Ellos trasmitieron anécdotas e incluso versos com-

${ }^{8}$ Long, Epictetus, 3 y 17. Long está convencido que sus ideas más profundas están muy lejos de lo principal del mensaje cristiano, a pesar de que haya notables paralelos entre las cosas que dice y el Nuevo Testamento. Su perspectiva ética incluye fuertes apelaciones al interés propio, que pide a las personas que valoren su identidad individual sobre todo lo demás. Long, Epictetus, 144. La lectura de Epicteto resulta difícil porque lo que dice se ha leído, en muchas ocasiones, como un eco directo del Nuevo Testamento.

${ }^{9}$ LONG, Epictetus, 17.

${ }^{10}$ Long, Epictetus, 271. En la época moderna, el Manual se convirtió en un suplemento estándar para el Nuevo Testamento y el cristianismo doctrinal. Sus principios eran demasiado heterodoxos y autónomos para que muchos los aceptaran sin objeciones, pero ofrecían un poderoso antídoto contra las presiones de la autoridad secular y teológica.

${ }^{11}$ Spanneut, M., "Epiktet," en Reallexikon für Antike und Christentum vol. V, 631-676. 
puestos, alabando su virtud y su carácter libre, a pesar de su pobreza, invalidez y esclavitud. Orígenes que escribió en el siglo III, cuando el cristianismo ya había reemplazado al estoicismo como la escuela filosófica dominante, dibujó un llamativo contraste entre Platón y Epicteto. "El hecho es que a Platón solo se le ve en manos de los que parecen ser doctos; a Epicteto, en cambio, vemos que lo admira todo el mundo, todo el que tenga alguna gana de aprovecharse, pues se dan cuenta del bien que les hace su lectura (Contra Celso, VI.2) ${ }^{12}$.

Algo que hay que señalar es la gran influencia que ha tenido su obra, tanto el Manual como las Disertaciones, en la historia del monacato cristiano. Sobre todo, por las muchas veces que es citado dentro de la literatura monástica. Aquí se encuentra el punto central de su influencia en el cristianismo ${ }^{13}$.

Lo que vamos a intentar en nuestro trabajo, después de hacer una breve presentación de la vida e influencias filosóficas de Epicteto y algunos aspectos centrales de su obra, es presentar su pensamiento teológico centrándonos sobre todo en sus Disertaciones, ya que a Epicteto, por encima de todos los demás estoicos, se le podría aplicar el título de teólogo, pues el hablar sobre Dios es central para su discurso y práctica filosófica ${ }^{14}$.

Además de hablar de Dios con frecuencia, lo hace de una manera piadosa. Para Epicteto Dios es la posibilidad y la dirección de la vida filosófica. La reverencia de Epicteto por Dios se extiende mucho más allá de su respeto por el orden natural o el temor por la belleza del mundo. Por supuesto, como cualquier estoico, cree profundamente en el carácter divino del orden providente del mundo (1.6.1), pero Dios para Epicteto no es simplemente idéntico a una determinada forma del mundo. Una y otra vez, Epicteto instruye a sus alumnos sobre el significado de la palabra Dios a través de una forma de hablar que muestra una calidez o confianza personal ${ }^{15}$.

Algo de lo que insistiremos es que Epicteto habla predominantemente de Dios de una manera teísta, aunque sin negar que también se refiera a Dios de una manera inmanente o panteísta. Dentro de la tradición

${ }^{12}$ LONG, Epictetus, 259-260.

${ }^{13}$ Spanneut, "Epiktet," 670 y 678.

${ }^{14}$ Kavin Rowe, C., On True Life. The Stoics and Early Christians as Rival Traditions, Yale University Press, New Haven \& London 2016, 44.

${ }^{15}$ Kavin Rowe, On True Life, 44-45. 
de la filosofía estoica, Epicteto puede caracterizarse porque reivindica, más que nadie, un lenguaje personalista al hablar de Dios.

\section{SU VIDA Y SUS INFLUENCIAS FILOSÓFICAS}

Epicteto nació en Hierápolis de Frigia -a unos 6 km. de Laodicea-, ciudad situada en el suroeste de la actual Turquía, en torno al año 50 d.C. No tenemos muchos datos de su vida pero todo indica que por nacimiento o en un estado temprano de su vida era esclavo y fue comprado por Epafrodito $^{16}$, secretario del emperador Nerón, y llevado a Roma. Epicteto todavía era un esclavo cuando su amo le permitió asistir a las enseñanzas de Musonio Rufo ${ }^{17}$ un eminente filósofo estoico, y parece que Epafrodito le liberó al poco tiempo. Epicteto fue el más famoso discípulo de Musonio Rufo -el llamado Sócrates romano- y probablemente bajo su mecenazgo abrió una escuela de filosofía en Roma. Entre los años 93 y 94 hay un decreto del emperador Domiciano en el que expulsa a los filósofos no solamente de Roma sino de toda Italia.

En este tiempo Epicteto se trasladó a Nicópolis, en la costa adriática del noroeste de Grecia, un importante enclave económico y político, donde se va a dedicar a la enseñanza de la filosofía y vivirá de las contribuciones de los alumnos.

Epicteto estableció en Nicópolis su escuela y allí vivió, exceptuando alguna corta visita a Atenas y Olimpia, hasta su muerte. Según las Disertaciones $(1,10 ; 2,14$, etc.) personas prominentes de su tiempo visitaron la escuela, entre ellas el emperador Adriano pues querían tener conversaciones con él buscando consejo. Epicteto describió su escuela como un hospital (3.23.30), y exhortaba a sus estudiantes a no salir de ella contentos, sino apenados, porque no estaban en buenas condiciones cuando llegaron,

${ }^{16}$ Epafrodito era uno de los ministros de más confianza de Nerón y estuvo presente durante su suicidio. Él sobrevivió alrededor de treinta años después y fue ejecutado por el emperador Domiciano en el año 95, quizás porque tuvo parte en la muerte de Nerón.

${ }^{17}$ LoNG, Epictetus, 14-15. Quizás Epicteto haya eclipsado a su maestro, pero es inolvidable la fuerte impresión que Musonio tuvo en Epicteto, y no influyó solamente en su estoicismo sino en su estilo de enseñar. Lo podemos ver en varios pasajes de las Disertaciones $(1,7.30-32 ; 3.23 .29)$. 
porque sus almas estaban enfermas del mismo modo que el cuerpo puede tener un hombro dislocado o un dolor de cabeza.

Epicteto caminaba cojo y algunos se lo atribuían a un defecto de nacimiento y otros, como consecuencia del abuso que sufrió durante su tiempo de esclavo. Epicteto nunca se casó, pero por razones de benevolencia al final de su vida adoptó a un niño. No conocemos con precisión la fecha de su muerte, pero debió ocurrir entre los años 130 y 135.

Epicteto, siguiendo a su maestro Musonio Rufo y a Sócrates, no escribió nada. El fue famoso durante su vida y tuvo gran influencia en la filosofía griega, pues todas las escuelas filosóficas se refieren a él ${ }^{18}$, y aunque no escribió para publicar, su discípulo Arriano de Nicomedia ${ }^{19}$, que a los 18 años durante los años 105-113 siguió sus lecciones en Nicópolis, publicó sus pensamientos en 8 volúmenes de Disertaciones (Diatribai), de los cuales han sobrevivido 4, y un resumen de la doctrina de las Disertaciones en forma de Manual ${ }^{20}$ (Encheiridion) que se convirtió en la obra más popular. Hoy día se cree que tanto las Disertaciones como el Manual reproducen el pensamiento filosófico de Epicteto, es decir, que Arriano fue fiel al pensamiento de su maestro, que era considerado como el Sócrates de su tiempo ${ }^{21}$. Una de las razones que tenemos para pensar que las obras representan el pensamiento genuino de Epicteto y no el de Arriano es porque están escritas en koiné, el griego coloquial también usado en el Nuevo Testamento, y no el lenguaje sofisticado literario que utilizará Arriano en sus otros escritos.

${ }^{18}$ HAdOT, La ciudadela interior, 128. Ya sabemos que en aquel período histórico un filósofo no era un personaje que escribía obras de filosofía, sino alguien que llevaba una vida de filósofo.

${ }^{19}$ Morford, Mark, The Roman Philosophers. From the Time of Cato the Censor to the death of Marcus Aurelius, Routledge, London \& New York 2002, 210. Arriano dice, en su prefacio, que no compuso los discursos ni que fue el primero que los dio a conocer, sino que circulaban antes que publicara su edición. Nos relata también que el trascribió palabra por palabra lo que escuchó en las lecciones de Epicteto. Hoy día se discute sobre la autoría de las Disertaciones y el Manual, pero no hay duda que estas obras reproducen los puntos de vista de Epicteto.

${ }^{20}$ Tabla de Cebes - Musonio Rufo, Disertaciones fragmentos menores - EPicteto, Manual Fragmentos (=BG =207), Traducción Paloma Ortiz García, Gredos, Madrid 1995.

${ }^{21}$ LoNG, Epicteto, 41 . El principal punto de interés sobre la relación de Arriano hacia Epicteto es la devoción de un alumno hacia su maestro. Arriano tomaba a Epicteto como el Sócrates de su tiempo, y él se podía considerar a sí mismo como el Jenofonte romano. 
Los estoicos reflexionaron sobre lo que dijo e hizo Sócrates ${ }^{22}$. Epicteto fue un gran admirador de Sócrates y consideró provechoso recordar siempre todo lo que hizo y lo que dijo (4.1.169). En su admiración y devoción por Sócrates, como un modelo a seguir, se apropió de Sócrates más profundamente que ningún otro filósofo desde Platón. Para Epicteto, Sócrates no era una aproximación a la sabiduría sino el paradigma de una persona genuinamente sabia. Raramente se refiere al ideal del sabio, él prefiere utilizar la expresión tradicional kalos kai agathos, "la persona excelente". En el Manual 51.3 Sócrates forma un paradigma autoritario para la vida filosófica ideal: "Incluso si aún no eres Sócrates, debes vivir como si quisieras ser Sócrates”. Pero, por supuesto, Sócrates no era un sabio estoico, sino que era un modelo de sabiduría que algunos estoicos tomaron por encarnar los principales atributos de su propio ideal filosófico.

Sócrates es el autor que más se menciona en sus obras ${ }^{23}$, también, aunque en un tono menor, aparece Diógenes de $\operatorname{Sinope}^{24}$, el fundador de

${ }^{22}$ Schofield, Malcom, "Stoic Ethics," en Cambridge Companion to the Stoics, INwood, Brad, (ed.), Cambridge University Press, New York 2006, 234. La verdad fundamental y el principio rector de la filosofía de Sócrates es (1) que lo único que vale la pena cuidar es el verdadero yo (el alma), no el cuerpo o cualquiera de los elementos externos que la fortuna puede o no poner en nuestro camino; y (2) que las únicas cosas que son intrínsecamente buenas y malas son condiciones del yo: la virtud y el vicio.

${ }^{23}$ Long, A., Epictetus, 69. Epicteto cita alrededor de 100 pasajes de los diálogos platónicos en los que se hace referencia a Sócrates. En el texto final del Manual 53, Arriano refleja las prioridades de Epicteto concluyendo con una cita de Sócrates en el Critón 43d, y parafraseando la Apología $30 \mathrm{c}$-d. "Anito y Meleto pueden matarme, pero no pueden perjudicarme."

${ }^{24}$ LoNG, A. A., Epictetus, 58-60. Las referencias a Diógenes en los discursos superan en número a las alusiones a cualquier filósofo individual, aparte de Sócrates. Su prominencia puede sugerir que Epicteto se presenta como un estoico cínico o al menos como un estoico con fuertes tendencias cínicas. En este sentido no podemos olvidar que las principales influencias del estoicismo de Zenón son socráticas y cínicas. Al canonizar a Sócrates, Diógenes y Zenón, Epicteto recuerda al fundador del estoicismo y a las dos grandes figuras que luego los estoicos consideraron como las aproximaciones más cercanas al ideal del sabio. Diógenes representa el cínico ideal enviado por Dios para ser un evangelista del estoicismo. Lo que lo diferencia del ideal estoico estándar no es su carácter o sistema de valores -esos son los mismos- que lo llaman a una vida nómada como "ciudadano del mundo", no vinculado a ninguna comunidad particular ni a la vida familiar, con el fin de "dar testimonio" de los principios estoicos. El ideal cínico de Epicteto es un filántropo universal, dotado no solo de la fuerza física y mental que exige su vocación, sino también de un ingenio y encanto naturales. 
la escuela cínica. El cinismo había tenido una poderosa influencia en la formación de la filosofía estoica, pues Zenón, su fundador, fue discípulo de Diógenes. En el tiempo de Epicteto la escuela cínica gozaba de una nueva popularidad ${ }^{25}$.

Hay una tendencia a tomar a Epicteto como un estoico ortodoxo, pero A. Long ${ }^{26}$ lo ve como un pensador y educador más independiente, estoico en su orientación general pero más socrático que estoico en algunas de sus propuestas y metodología. Su inequívoca fe en la voluntad autónoma y las preconcepciones innatas de los seres humanos sobre la bondad y maldad son algo distintivo y central en su filosofía. Al igual que el Sócrates de los primeros diálogos de Platón, Epicteto no impone doctrinas elaboradas a su audiencia. Al contrario, los exhorta a que se conozcan a sí mismos y practiquen el autoexamen ${ }^{27}$, y para descubrir una fuente de bondad que es puramente interna, independiente de las contingencias externas y capaces de generar ambas la integridad y felicidad personal.

\section{LA FILOSOFÍA COMO FORMA DE VIDA Y EL IDEAL DEL SABIO}

La concepción filosófica de Epicteto valora más los hechos que las palabras. El verdadero estoico no es quien conoce y recita las enseñanzas de Crisipo, sino más bien quien actúa o se comporta de acuerdo con esas palabras. La tarea de la filosofía es comprender la Naturaleza, para que

${ }^{25}$ SCHOFIELD, "Stoic Ethics," 235. Epicteto afirma (3.22) que lo que distingue al cínico es su forma de vida: abierta al escrutinio público constante, lo que le da una autoridad especial para recordar a las personas sus fallos. Y a través de su propio carácter y comportamiento nos muestra, ante todo, una intrepidez y libertad de espíritu y de expresión, de que lo que dice sobre el bien y el mal es verdad.

${ }^{26}$ LONG, A., Epictetus, 92.

${ }^{27}$ Sorabji, Richard, "Epictetus on proairesis and Self," en MASON, S. Andrew and Scaltsas, Theodor., (eds.) The Philosophy of Epictetus, Oxford University Press, Oxford \& New York 2007, 97. El término proairesis sugiere que Epicteto tiene una idea de autoconciencia y propondría un "volver al interior" en la filosofía, la idea que para encontrar la verdad debemos mirar en nuestro interior. En 3.22.38-9, Epicteto recomienda volverse sobre uno mismo para descubrir las verdaderas preconcepciones innatas sobre el bien. SPANNEUT, "Epiktet," 610. Epicteto consigue lo que el estoicismo había conquistado lentamente: la internalización de la acción humana. 
uno pueda vivir de acuerdo con ella y así alcanzar la felicidad. Para Epicteto, el estudio de las teorías filosóficas siempre está subordinado a este objetivo práctico ${ }^{28}$. Por lo tanto, la filosofía es un arte de vivir ${ }^{29}$, un arte que, como otras artes y oficios, se orientará hacia un resultado práctico. Y como otras artes será necesaria no solo para aprender los principios que sustentan el arte de vivir, sino también para ejercerlos. Así nos dice: El constructor no viene y dice: "oídme hablar sobre construcciones," sino que, una vez que acuerda la construcción de una casa, haciéndola demuestra que posee el arte (3.21.4). El filósofo debería hacer exactamente lo mismo, sugiere Epicteto, exhibiendo sus habilidades no con buenas palabras sino con buenas obras, es decir, son las acciones las que permiten reconocer al verdadero filósofo. No debería sorprendernos, entonces, que Epicteto muestre una actitud ambivalente hacia los textos escolares ${ }^{30}$.

Los estoicos dicen que el objetivo de la vida es vivir de acuerdo con la naturaleza humana racional que se adecua con la práctica de la virtud. Pero no se trata solamente de la naturaleza humana, ya que estamos programados para vivir de acuerdo con el universo natural del que formamos parte. Para entender lo que es vivir conforme a la naturaleza, debemos tener en cuenta que la racionalidad es el culmen de los atributos humanos, pero es un atributo que compartimos y se deriva del mismo universo. En otras palabras, nuestra noción de la naturaleza humana no puede limitarse a la reflexión sobre el impulso de preocuparnos por la salud, las posesiones y cosas similares: lo que podría llamarse lo meramente humano. El vivir según la naturaleza no es la receta de cómo el proyecto ético humano debe

${ }^{28}$ Sellars, Stoicism, 28-29 y 31. El filósofo que pasa todo su tiempo analizando textos y nunca pone sus contenidos en práctica es un fracasado. Para Epicteto, no es Crisipo quien destaca como su modelo filosófico, sino más bien Sócrates, quien expresa su filosofía en hechos en lugar de palabras. La filosofía no trata de comprender e interpretar textos filosóficos, sino que es también algo más práctico y existencial.

${ }^{29}$ LONG, Epictetus, 97. La concepción filosófica de Epicteto puede resumirse como el "arte de vivir" (1.15.2).

${ }^{30}$ SELLARS, Stoicism, 26-27 y 29. Los estudiantes estoicos que comprendieron con éxito la filosofía de Epicteto centrarían toda su atención en la transformación de su camino de la vida en un arduo intento de acercarse a la vida del sabio. Como Epicteto, aspirarían a ser como Diógenes el Cínico y, sobre todo, como Sócrates. Pero lo que no harían es involucrarse en estudios de textos escolares o escribir comentarios sobre ellos. Esa puede ser una de las razones por las cuales el estoicismo disminuyó rápidamente y por lo qué se perdieron muchos textos antiguos. 
llevarse a cabo, sino más bien una descripción de cómo es posible que tengamos éxito en ese proyecto. Si practico la virtud, mi manera de vivir es congruente con el orden del universo, y por lo tanto vivo una vida racional, hay una interrelación entre practicar la virtud, vivir según la naturaleza y seguir la naturaleza racional, y en vivir de esta manera consiste la felicidad. Tengo que recordar que soy un ciudadano del universo, una parte, y al ejercitar mi razón, no trato de obtener una ventaja privada ni deliberada como si estuviera separado del conjunto ${ }^{31}$.

Pero Epicteto duda que encuentre muchos estoicos entre los estudiantes de su escuela (que consideren que la virtud es la clave de la felicidad independientemente de las circunstancias). Por supuesto, todos sus alumnos podrán recitar argumentos y doctrinas estoicas (2.19.20-25), pero como hemos visto para Epicteto, eso no es suficiente. El verdadero estoico debe ser capaz de traducir esas doctrinas en un comportamiento concreto. No es suficiente decir que uno puede ser virtuoso y, por lo tanto, feliz, independientemente de las circunstancias; uno, en realidad, debe ser feliz independientemente de las circunstancias, ya sea que esté en peligro, en desgracia, enfermo o moribundo ${ }^{32}$.

Esta concepción de la filosofía como un arte para tratar las enfermedades del alma, que solo puede practicar uno mismo, forma el contexto para nuestro pasaje inicial de Epicteto (1.15.2). Cuando Epicteto dijo que la vida de cada individuo es el material del arte de vivir, estaba respondiendo a un hombre que le preguntó cómo podría evitar que su hermano se enoje contra él. La respuesta de Epicteto fue decir que esta persona debería estar más preocupada por su propia reacción emocional a la ira de su hermano que con la cólera de su hermano. Si el hombre quiere retomar la filosofía para tratar su propia enfermedad mental, entonces debería hacerlo, pero no debería pensar que podía curar la ira de su hermano. Solo su hermano puede hacer eso. Aquí vemos que los estoicos desarrollan un tema que se origina con Sócrates, a saber, la idea de que la tarea más urgente a que nos enfrentamos es el cuidado de nuestras propias almas $(3.12 .15)^{33}$. Nadie puede hacer esto por nosotros; todos debemos dominar

${ }^{31}$ SChofield, "Stoic Ethics," 244-246.

32 Sellars, Stoicism, 32.

${ }^{33}$ SELLARS, John., The Art of Living. The Stoics on the Nature and Function of the Philosophy, Bloomsbury Academy, London \& New York 2009², 36-38. La tarea de Sócrates del 
el arte del "cuidado de uno mismo". Así, el médico estoico del alma no es un tipo de terapeuta evangélico que intenta curar las almas de todos los que conoce; más bien se centra en una forma más personal y tarea privada $^{34}$, aunque, como Sócrates y Diógenes el Cínico, puede alentar a otros a embarcarse en ese mismo trabajo personal por ellos mismos ${ }^{35}$.

La filosofía se concibe como un arte de curar el alma por lo que es un arte de vivir; ya que la transformación de nuestras almas tiene un impacto directo en nuestras acciones y en nuestra forma de vida y al convertir nuestras vidas vamos cambiando también nuestras almas. Si la filosofía es un arte de vivir dedicado a transformar nuestra forma de vida, entonces el objetivo final de ese arte es convertir la vida de uno en la vida de un sabio. Todas las partes de la filosofía estoica están, a su manera, dirigidas hacia este fin $^{36}$.

Si bien puede ser imposible llegar a ser perfecto hasta el punto de la infalibilidad, es concebible, en palabras de Epicteto, llegar a ser como Sócrates, no importa cuán difícil pueda ser esa tarea, e incluso si el "Sócrates" que tenemos en nuestra cabeza no es idéntico a la figura histórica. Lo más importante es darnos cuenta cómo en la preocupación estoica por el sabio se destaca su orientación práctica. La tarea filosófica fundamental es transformar la propia forma de vida en la vida de un sabio ${ }^{37}$.

Epicteto vincula el uso correcto de la razón con la salud del alma. La razón no funciona sola. Para Epicteto, no hay tal cosa como el pen-

cuidado del alma consiste en enseñar la virtud a través del examen. $1^{\circ}$ ) Un autoexamen o reflexión interior, en el que uno se conoce y se examina a sí mismo. $2^{\circ}$ ) El examen o cuidado de los demás, de la ciudad o de los ciudadanos, aquí hay un examen o discurso entre varios, una especie de discernimiento intersubjetivo.

${ }^{34}$ 3.13.5-12. Aunque somos sociables por naturaleza y amantes de la compañía, se insiste en que el sabio tiene que bastarse a sí mismo y tiene que vivir consigo mismo. Del mismo modo, que Zeus convive consigo mismo y se mantiene en paz en sí mismo y medita cómo es su propio gobierno, así también nosotros debemos hablar con nosotros mismos, sin necesitar de los otros.

${ }^{35}$ Sellars, Stoicism, 35. Schofield, "Stoic Ethics," 234. Epicteto (3.21.18-19) recuerda a Sócrates, Diógenes y a Zenón que son para él sus referentes y modelos. No piensa en ellos como filósofos semejantes a él, sino que los tres adoptan un modo de filosofía del cuidado, que en términos genéricos se podría llamar terapéutica. El cinismo y el estoicismo son simplemente versiones de la ética socrática.

${ }^{36}$ Sellars, Stoicism, 36.

${ }^{37}$ Sellars, Stoicism, 41. 
samiento o los juicios sobre impresiones que pueden hacerse en abstracto sobre el propio hábito del filósofo. La razón no puede "aplicar su remedio" aparte de la capacidad del portador de la razón para mantenerse saludable. En resumen, para Epicteto, ir a la escuela en Nicópolis es tener la esperanza de curarse. La filosofía no tiene nada que ver con aprender principios que no tratan nuestra enfermedad, como si solo nos ofrecieran un "colirio" cuando no tenemos nada malo en nuestros ojos (2.21.15-22). En cambio, la única forma en que podemos ser curados o, para utilizar la metáfora favorita de Epicteto, ser liberados de la esclavitud. “Con qué propósito fuiste a los filósofos?" (4.1.83). "Para ser liberado" es su respuesta. De hecho, "todos los días cuando te estás entrenando en el gimnasio, no digas que estás "filosofando," “QQué frase tan arrogante!", sino que eres un esclavo presentando tu liberador en el tribunal. En realidad, esa "es la verdadera libertad" (4.1.113). Que la libertad ofrecida por la filosofía se sustenta fundamentalmente en erigir una ciudadela interior impenetrable es tan obvio en Epicteto como todo lo que enseña (4.1.86) ${ }^{38}$.

En toda la Antigüedad se considera a la sabiduría un modo de ser, un estado en el que el hombre es radicalmente distinto de los demás, en el que es una especie de superhombre. Si la filosofía es la actividad por medio de la cual el filósofo se ejercita en la sabiduría, este ejercicio consistirá necesariamente no solo en hablar y en disertar de cierta manera, sino en ser, en actuar y en ver el mundo de un cierto modo. Si la filosofía no solo es un discurso, sino una elección de vida, una opción existencial y un ejercicio vivido, es porque es el deseo de la sabiduría. En la noción de sabiduría se incluye la idea de un saber perfecto; pero este saber no consiste en la posesión de informaciones acerca de la realidad, sino que también es la actividad más elevada que el hombre puede ejercer y se vincula íntimamente con la excelencia, la virtud del alma ${ }^{39}$.

La figura del sabio tiene un papel decisivo en la elección de la vida filosófica. Se presenta al filósofo como un ideal descrito por el discurso filosófico más que como un modelo encarnado por un personaje vivo. Los estoicos decían que el sabio es sumamente raro, hay muy pocos, tal vez uno, quizás ninguno. En este punto, el resto de las escuelas son casi de la misma opinión, salvo los epicúreos, que no dudan en venerar a Epicuro como el

\footnotetext{
${ }^{38}$ Kavin Rowe, On True Life, 58-59.

${ }^{39}$ HADOт, Pierre, ¿Qué es la filosofía antigua?, FCE, México1998, 240-241.
} 
sabio por excelencia. El único sabio universalmente reconocido por todas las escuelas es Sócrates ${ }^{40}$, este sabio desconcertante que no sabe que lo es ${ }^{41}$.

Para los estoicos y cínicos, Sócrates fue el modelo del filósofo ideal, y precisamente el filósofo cuya principal enseñanza es su vida y su muerte. Recordemos el bello texto de Plutarco que dice justamente: Sócrates era filósofo, no por enseñar en una cátedra, sino porque hablaba con sus amigos, bromeaba con ellos; iba también al ágora y, después de todo esto, tuvo una muerte ejemplar. Así pues, la práctica de la vida cotidiana de Sócrates es su verdadera filosofía. Sócrates se hizo filósofo paseando con sus amigos, comiendo y discutiendo con ellos, yendo como ellos a la guerra y finalmente bebiendo la cicuta, y no enseñando desde lo alto de una cátedra. Demostró así que la vida cotidiana da la posibilidad de filosofar ${ }^{42}$.

Además, Epicteto entiende el papel del filósofo como alguien que ha sido designado por Dios para una misión divina, es decir, la misión de ser su mensajero. Hay dos pasajes en las Disertaciones que presentan explícitamente al filósofo como mensajero de Dios (3.1.36-7 y 3.22.38; 69). Por esta razón, Epicteto presenta al filósofo como alguien que ha sido enviado providencialmente por Dios para llevar su mensaje a los seres humanos, y es, en este sentido, el más noble mensajero de Dios ${ }^{43}$.

Según Epicteto, por esta razón, el filósofo estoico Eufrates de Tiro no se presenta ni quería ser reconocido filósofo por lo que dijo o por su

${ }^{40}$ Sellars, The Art of Living, 82. Sócrates concebía la filosofía como un arte relacionado con el cultivo de la sabiduría o la excelencia humana. Sócrates era un filósofo en el sentido etimológico de la palabra, buscaba la sabiduría, pero él no la poseía. Hay una distinción clara entre filosofía y sabiduría, la sabiduría es lo que se busca por medio de la filosofía.

${ }^{41}$ HADOT, ¿Qué es la filosofía antigua?, 144.

${ }^{42}$ Hadot, Pierre, La filosofía como forma de vida. Conversaciones con Jeannie Carlier y Arnold I. Davidson, Alpha Decay, Barcelona 2009, 156 y 183-184. Hadot, Pierre, Los ejercicios espirituales y Filosofía antigua (=Biblioteca de ensayo 50), Siruela, Madrid 2006, 302. La Antigüedad le concedió a Sócrates estatuto de filósofo, más por su forma de vivir y morir que por sus discursos. Y la filosofía antigua siguió siendo socrática en la medida en que nunca dejo de presentarse a sí misma como una forma de vida más que como un discurso de carácter teórico. No se entiende por filósofo al profesor o escritor, sino al hombre que ha elegido determinada forma de existencia, que ha adoptado cierto estilo de vida.

${ }^{43}$ Ierodiakonou, Katerina., "The Philosopher as God's Messenger," en Mason, S. Andrew and Scaltsas, Theodor., (eds.) The Philosophy of Epictetus, Oxford University Press, Oxford \& New York, 56 y 60. 
apariencia, por ejemplo, vistiendo el atuendo de filósofo y la barba, sino por la forma en que se comportaba en la vida cotidiana. Es decir, quería ser reconocido filósofo por su comportamiento en las cosas ordinarias como comer, beber o caminar (4.8.17-20). El filósofo, por lo tanto, es alguien superior que se distingue de los humanos ordinarios, como la franja roja en un manto distingue a un senador romano de otros ciudadanos romanos. El filósofo vive una vida que exhibe su comprensión de lo divino, orden de las cosas en los asuntos cotidianos, incluso cuando se enfrenta a dificultades. Y es esta forma de vida, una vida filosófica, que se supone que transmite el mensaje divino a los seres humanos ordinarios que, por alguna razón, son incapaces de dedicarse a la filosofía ${ }^{44}$.

Epicteto presenta a Sócrates y Diógenes como modelos de vida a seguir $(4.1 .152 ; 159 ; 170 ; 4.8 .31 ; 4.5)$. Epicteto utiliza la analogía médica según la cual la escuela del filósofo es un hospital (3.23.30), donde los seres humanos buscan curarse de sus deseos equivocados y falsas creencias. Pero la cura es factible solo cuando el médico sabe aplicar sus conocimientos sanitarios. La característica central, por lo tanto, del papel del filósofo como mensajero de Dios es curar a los seres humanos de sus debilidades y ayudarlos para lograr una vida mejor; en otras palabras, el papel del filósofo se presenta como la salvación para los seres humanos ${ }^{45}$.

\section{LA ORIENTACIÓN TEOLÓgICA DEL PENSAMIENTO DE EPICTETO}

Algo que hay que destacar del pensamiento de Epicteto es su límpida orientación teológica. Epicteto sitúa a Dios como el punto de partida y fundamento de su filosofía, es decir, no se puede entender su filosofía sin esta orientación religiosa. La pregunta es si este recurso de Epicteto a la teología es una traición a su racionalismo estoico y dialéctica socrática ${ }^{46}$. Es de reseñar el texto (1.14.1-17) donde encontramos una descripción del "principio de simpatía" o interdependencia de todo lo creado, es decir, existe una armonía entre la esfera divina y la vida humana. Se puede re-

\footnotetext{
${ }^{44}$ Ierodiakonou, "The Philosopher," 62-63.

${ }^{45}$ Ierodiakonou, "The Philosopher," 68.

${ }^{46}$ LONG, Epictetus, 181.
} 
flexionar sobre el gobierno divino, cómo la divinidad contempla todo lo que sucede o gobierna todo lo creado, y sobre las cosas humanas. Pero el tema medular de este discurso se refleja en que los seres humanos están dotados con la capacidad de examinarse a sí mismos y conocer la presencia del espíritu divino en nuestra alma. "Las almas están tan atadas y unidas a la divinidad, por ser partes y fragmentos suyos" (1.14.6.), por lo que hay que descubrir la presencia de la divinidad dentro de nosotros (1.14.14). Epicteto creía que nuestro razonamiento y sentido moral son una parte del gobierno divino del mundo, cuyo orden cósmico es un patrón de la armonía que nosotros deberíamos reproducir en nuestros pensamientos y acciones.

Una de las características más llamativas de la teología estoica es una concepción bastante fluida de Dios ${ }^{47}$. Epicteto está interesado en hablar de la naturaleza animada, en la cual no solamente incluimos a los seres humanos y otros animales sino ante todo a Dios. El único nombre propio que Epicteto menciona más que a Sócrates es Zeus. Ya sea que hable de Zeus o Dios o la Naturaleza o los dioses, está comprometido con la creencia de que el mundo está organizado providencialmente por un poder divino cuya acción creadora alcanza su máxima expresión en los seres humanos. Algo que llama la atención de la teología de Epicteto, en lo que insistiremos más adelante, es el pertinaz tono personalista. Epicteto, más enfáticamente que cualquier otro estoico, habla de Zeus o Dios en términos que tratan del principio divino del mundo como una persona muy cercana a nosotros mismos, como un aspecto integral de nuestra propia alma ${ }^{48}$.

Dentro de los rasgos personalistas, Epicteto caracteriza a Dios como "quien se preocupa de nosotros y nos cuida paternalmente" (3.24.3), e incluso les dice a sus alumnos que ser adoptados por el emperador es de un status menor que ser hijos de Dios (1.3.2). Epicteto exhorta a sus discípulos a que acudan a Dios para que les ayude a superar las dificultades (2.18.29) y a considerar a los esclavos como hermanos, pues ellos son también hijos de Zeus (1.13.3-4), es decir, todos son hermanos que comulgan de la misma razón, por lo tanto, todos tienen el mismo valor absoluto. Epicteto insiste en que la esencia de la divinidad y la naturaleza del bien coinciden (2.8.1). En todas las cosas, él y sus discípulos deben mirar a Dios

\footnotetext{
${ }^{47}$ Algra, Keimpe, "Stoic Theology," en Cambridge Companion to the Stoics, Inwood,
} Brad, (ed.), Cambridge University Press, New York 2006, 169.

${ }^{48}$ LONG, Epictetus, 143. 
como su creador, padre, protector y tienen que intentar hacer la voluntad de Dios, agradecerle y complacerle $(1.9 .4 ; 4.4 .21 ; 4.12 .11)$. En fin, reconocer nuestro parentesco y procedencia de la divinidad, pues somos una chispa o fragmento divino $(1.3 ; 1.14 .6 ; 2.8 .11)$.

Epicteto habla del creador divino del mundo con el fervor de san Pablo o san Agustín. Su tono tampoco se ve afectado por el hecho de que, además de hablar de Dios o de Zeus, hable también de los dioses en plural. El monoteísmo en el sentido estricto del judaísmo, cristianismo e islamismo no era un problema doctrinal del estoicismo. Como la divinidad estoica está en todos los lugares, los filósofos estoicos podían acomodarse a los dioses en plural. De hecho, aplicaron los nombres de los dioses griegos y de las religiones populares romanas a los elementos: tierra, aire, fuego y agua, y especialmente a los cuerpos celestes. Estrictamente, aunque estos dioses son solo formas simbólicas de referirse a los constituyentes más poderosos del mundo, todos deben su existencia al único "principio activo" llamado Dios en singular o Zeus ${ }^{49}$.

El lenguaje teológico de Epicteto manifiesta una fe y experiencia personal tan profunda como la pueda tener un judío, cristiano o musulmán. $\mathrm{Al}$ igual que estas religiones, al menos en su rigor doctrinal, Epicteto rechaza la existencia de un principio del mal en el universo. Crisipo estaba preocupado por reconciliar la providencia con los desastres naturales y el sufrimiento del inocente, pero Epicteto no presta atención a la teodicea. No hay nada malo de lo que Dios sea responsable porque la maldad pertenece exclusivamente a las deficiencias humanas. La felicidad que Dios pretende para todas las personas solamente es posible si armonizaran sus mentes y valores con las leyes propias y la naturaleza del mundo ${ }^{50}$.

Epicteto difiere de los estoicos antiguos en la medida en que usa un lenguaje personalista sobre Dios; esto puede explicarse en parte por su perspectiva personal, pero también por el propósito de las Disertaciones, en el que la providencia de Dios y su estatus como ejemplo ético son más importantes que los aspectos cosmológicos que jugaron una parte importante en el estoicismo antiguo ${ }^{51}$. Las Disertaciones ofrecen una concepción

${ }^{49}$ LONG, Epictetus, 144.

${ }^{50}$ LONG, Epictetus, 145.

${ }^{51}$ LONG, Epictetus, 182. La teología en el estoicismo antiguo no es el fundamento ni incluso una parte de la ética, sino la culminación de la física, el estudio de la naturaleza. El 
teísta bastante sorprendente de Dios, es decir: una concepción de Dios como persona, que nos ve, que nos habla, que nos ayuda y a quien podemos dirigir oraciones. Ciertamente, hay huellas de lo que podríamos llamar una concepción panteísta de la deidad estoica en Epicteto, por ejemplo, donde Dios se conoce como "el cosmos" o "la naturaleza" (1.4.18; 3.24.94). Sin embargo, incluso en tales pasajes, el panteísmo a menudo se funde en el teísmo, viendo el uso que hace Epicteto de fórmulas como "la voluntad de la naturaleza" (Ench. 26). En general, la relevancia del lenguaje teísta en las Disertaciones es realmente extraordinario ${ }^{52}$.

Podemos reseñar tres interpretaciones de la comprensión de la teología estoica. Bonhöffer ${ }^{53}$ sostenía que Epicteto no se apartó del estoicismo convencional en absoluto. Afirmó que la tensión entre elementos panteístas y teístas que encontramos en Epicteto es algo inherente a la teología estoica de todos los tiempos. Esta visión no ha sido seguida por la corriente principal de los eruditos epictetanos del siglo XX que, en general, vieron a Epicteto un caso excepcional. Estos pensadores, entre otros Lagrange $^{54}$ y Jagu $^{55}$, opinan que Epicteto difiere del estoicismo antiguo y presenta un Dios muy admirable y casi personal, es decir, fórmulas que fácilmente un cristiano podría aceptar. Jagu, explícitamente, contrasta el

estoicismo tradicional va de abajo hacia arriba, es decir, el valor supremo de la racionalidad o la excelencia del carácter están arraigados en la naturaleza humana.

${ }^{52}$ Algra, Keimpe., "Epictetus and the Stoic Theology," en Mason, S. Andrew and Scaltsas, Theodor., (eds.) The Philosophy of Epictetus, Oxford University Press, Oxford \& New York, 33. AlgRA, "Stoics Theology," 169. Al señalar que Epicteto habla predominantemente de Dios de una manera teísta, estamos asumiendo un aspecto de la teología estoica que ha estado presente desde el principio. SPANnEut, "Epiktet," 606. La mayoría de las expresiones personalistas que se pueden encontrar, de forma aislada, en el estoicismo antiguo, no excluyen necesariamente el panteísmo politeísta. Sin embargo, la repetición persistente de estas expresiones en Epicteto revela que va más allá de las formulaciones del estoicismo antiguo. El Dios de Epicteto se presenta como fuera del universo, pero al mismo tiempo como creador providente $(2.14 .25 / 27)$ y padre protector $(1.3 .1 ; 1.9 .7)$ muy cercano en su relación con las personas.

${ }^{53}$ BonHÖFfer, F. Adolf., The Ethics of the Stoic Epictetus, Peter Lang Publishing, New York 2000.

${ }^{54}$ Lagrange, M. J., "La philosophie religeeuse d'Épictète et le Christianisme," en Revue Biblique Internationale 9 (1912), 5-21.

55 JAGU, Armand, "La morale d'Épictète et le christianisme," en $A N R W$, vol. 2, 36.3 (1989), 2164-2199. 
teísmo de Epicteto con el dios impersonal y material del estoicismo antiguo. Finalmente, el tercer enfoque estaría representado por Anthony Long en su libro Epictetus: A stoic and socratic Guide to Life (2002). En principio, Long estaría de acuerdo con los eruditos franceses, ya que Bonhöffer no habría resaltado suficientemente los elementos personalistas como algo peculiar de la teología de Epicteto. Sin embargo, Long prefiere ver estas características típicas como una cuestión de compromiso o actitud personal más que como un cambio sustancial con la ortodoxia estoica. En su opinión, estamos tratando con un compromiso religioso personal que ha sido conformado, en gran medida, por la admiración de Epicteto por Sócrates, y, en efecto, Sócrates sería el responsable de los acentos personalistas de su teología, por lo que deja intacta la sustancia de la teología estoica $^{56}$.

Según Keimpe Algra ${ }^{57}$ no es fácil dar una respuesta precisa con relación a la teología de Epicteto. La relación entre el panteísmo y el teísmo personalista en el estoicismo en general y en Epicteto, en particular, todavía necesitan más aclaraciones. Pero, la teología de Epicteto no constituye una gran fractura entre Epicteto y el estoicismo antiguo. Se puede ver, por un lado, que el estoicismo antiguo no era exclusivamente panteísta como, con frecuencia, se supone, mientras que, por otro lado, el teísmo personalista que podemos atribuir a Epicteto no parece haber sido tan radical después de todo. Algra intenta fundamentar estas afirmaciones mediante un estudio comparativo de algunos aspectos relevantes de las teologías de los primeros estoicos, por un lado, y de Epicteto, por otro.

En la medida en que el panteísmo implica la asunción de la identidad de dios y el mundo, o la suposición de que dios está presente en el cosmos y solo allí, los primeros estoicos eran panteístas. Esto no necesita discusión. Pero sí podemos señalar que el panteísmo estoico antiguo parece haber tenido dos formas, una perspectiva monista o bien una dualista: se podía afirmar que Dios era idéntico al mundo, pero también podría considerarse como el principio activo, o pneuma formativo, que está trabajando en el cosmos. La teología estoica contiene también una fibra teísta. El dios cósmico no es eo ipso un dios impersonal. Al contrario, visto como un principio formativo inmanente, Dios podría ser etiquetado, como Zenón lo

\footnotetext{
${ }^{56}$ Algra, "Epictetus and the Stoic Theology," 33-34.

${ }^{57}$ Algra, "Epictetus and the Stoic Theology," 35-36.
} 
expresó, no solo como "se parece a un artesano", sino en realidad como "artesano", o incluso un "padre". Por tanto, no es simplemente racional, sino también providencial y feliz. De hecho, se consideraba que la racionalidad de Dios y la racionalidad del cosmos no difería de la racionalidad humana. Dios, en cuanto principio rector racional y providencial, podría verse como una "persona" con propósitos e intenciones. Por lo tanto, la providencia podría identificarse como "la voluntad de Zeus". Aunque el dios estoico no debe concebirse antropomórficamente en un sentido físico relacionado con su forma, se parece a los humanos en cuanto a su racionalidad providencial y diversas cualidades relacionadas con esto. Es virtuoso y feliz, y como tal, un ejemplo a seguir ${ }^{58}$.

Por lo que podemos ver, el panteísmo estoico podría, en cierta medida, fusionarse con el teísmo, especialmente donde una perspectiva más física da paso a una centrada en la actividad providencial de Dios (Dios como demiurgo y padre) o en la semejanza y afinidad entre el hombre y dios (dios como un ejemplo virtuoso). Sin embargo, incluso Crisipo y otros estoicos antiguos estuvieron, en cierto modo, comprometidos con una concepción personalista de Dios, aunque este personalismo tenía sus límites. El dios estoico bien puede ser, como los humanos, un ser racional, sin embargo, a diferencia de ellos, o al menos a diferencia de los que no son sabios, es un ser perfectamente racional y nada más. De ahí que su actitud hacia el mundo, y hacia nosotros, se caracterice solo por la racionalidad, no por las emociones. No hay lugar para la gracia, no hay relación de do$u t$-des, no hay amor divino, ni ira divina. A nivel del mundo, en general, el cuidado providencial de Dios consiste solo en una cosa, es decir, en que el mundo está estructurado de la manera más racional y perfecta posible ${ }^{59}$.

Aunque el estoicismo convencional permitió el teísmo, debemos ser conscientes de la naturaleza y las limitaciones del personalismo que implica esta marca particular del teísmo. En Epicteto, en cambio, se puede apreciar una mayor insistencia en el lenguaje teísta y personalista.

${ }^{58}$ Algra, Keimpe, "Stoic Philosophical Theology and Greco-Roman Religion," en Salles, Ricardo (ed.) God and Cosmos in Stoicism, Oxford University Press, Oxford and New York 2009, 244. Long, Epictetus, 170. Cuando Dios es concebido de modo panteísta, como físicamente presente en todos los seres, es difícil entender qué propiedades podría tener para constituir el paradigma del carácter humano virtuoso, digno de confianza, magnánimo, etc. Pero los antiguos estoicos no compartieron ese desconcierto.

${ }^{59}$ Algra, "Epictetus and the stoic Theology," 40. 
Veamos algunas características de la concepción de Epicteto de cómo Dios se relaciona con el hombre, que dios nos contempla, nos habla ${ }^{60} \mathrm{y}$ nos ayuda. La idea de que Dios nos observa o nos supervisa constituye un tema recurrente en Epicteto. En 1.14, en el tratado titulado "Que la divinidad contempla a todos los hombres", explica lo que esto significa en realidad. La relación de Dios con nosotros se describe primero (1.14.110) en términos de simpatía cósmica universal. Epicteto continúa explicando que, de hecho, el que "nos ve" es nuestro daimon, es decir, dios en nosotros, un fragmento del dios cósmico. En otras palabras, es en virtud de nuestra propia racionalidad, que es una parte de dios, que nunca estamos solos y, en cierto sentido, siempre "observados". Estas afirmaciones: que nuestro "yo racional" es una parte del dios cósmico y que nosotros tenemos un daimon interno parece que son ortodoxas ${ }^{61}$.

Se ha afirmado, a veces, que Epicteto presenta un elemento novedoso al caracterizar la relación entre el hombre y dios como entre "padre" e "hijo". En este punto también tenemos que tener precaución. En ciertos contextos, Epicteto usa este término "padre" simplemente para referirse a la idea de que Dios es la causa cósmica providente de las cosas. Dios nos ha provisto tanto de la vida como de los otros bienes externos y, lo más importante, con lo único que realmente cuenta: la razón. En otras palabras, aparte de referirse al cuidado providencial general de Dios, habla de la paternidad de Dios, pero no implica ninguna preocupación específica y personal por las personas. Por el contrario, cuando ciertos individuos son llamados "hijos" de Dios, esto se debe a que, por su parte, exhiben una ac-

${ }^{60}$ Algra, "Epictetus and the stoic Theology," 45. La idea de que Dios nos habla también se destaca en Epicteto. Sin embargo, no debemos tomar el lenguaje teísta al pie de la letra. Cuando Epicteto habla de Dios dando órdenes específicas, lo que en realidad Dios "dice" es simplemente lo que nos pasa. Al decir que Dios nos está "hablando" es una forma abreviada para alcanzarnos a través del logos de sus mensajeros, los filósofos.

${ }^{61}$ Algra, "Epictetus and the stoic Theology," 42-43. No es fácil interpretar estos textos pues Epicteto a veces habla de este daimon interior como nuestro yo racional, y en otras ocasiones como una especie de alter ego o superego o espíritu guardián independiente. La última interpretación facilitaría la versión de que Dios nos ve y nos ayuda. LonG, Epictetus, 166. Epicteto a veces habla de que la presencia de esta voz pluraliza a la persona, o hace a la persona distinta de su daimon. Esto debe verse como una metáfora o, mejor, como una forma de articular la idea de que el escuchar y obedecer a nuestro ser normativo está de acuerdo con la divinidad que supervisa el mundo. 
titud especial hacia Dios, en lugar de que sea Dios el que se preocupe por ellos. Dios es una fuente providencial de los bienes y de la razón, y como tal le debemos amar y seguir ${ }^{62}$.

Otro aspecto que aparece en los textos de Epicteto es la oración, cómo los humanos se dirigen a Dios. La pequeña oración de Cleantes que encontramos al final del Encheiridion se cita o es parafraseada, muchas veces, a lo largo de las Disertaciones. La oración de petición es una manifestación del teísmo por excelencia, en la medida en que se observa una forma de dirigirse a dios, pidiéndole que nos otorgue algún favor. No es fácil encajar la oración de petición con la concepción estoica ortodoxa de Dios. Primero, dada la identificación de Dios con la providencia o el destino, no es fácil que Dios intervenga en nuestra vida. Segundo, en una línea de pensamiento estoico, la gente reza normalmente en las oraciones de petición por (salud, riqueza, etc.) que son consideradas como cosas indiferentes, que tienen poco o ningún valor: lo único que cuenta es la racionalidad y la virtud. Por lo tanto, el que se tome la teología estoica en serio, no dejará mucho espacio a la oración de petición ${ }^{63}$.

Podemos resaltar dos aspectos del Dios estoico que son relevantes. Primero, dios como una fuente de cuidado providencial general y, segundo, dios como ejemplo, como aquello a lo que nuestra racionalidad, nuestro daimon personal, debe adaptarse y conformarse. Como he indicado antes, estos dos aspectos del dios estoico, ser una fuerza providencial y un ejemplo ético, evocan un enfoque más teísta también en el estoicismo antiguo. Por otro lado, dado su propósito general, es normal que las Disertaciones ignoren en la práctica los aspectos más físicos y "panteístas" de la teología estoica tradicional, como la naturaleza neumática de Dios, o la forma como gobierna los diferentes procesos cosmológicos, aspectos que ocupan un lugar destacado en las fuentes de las que depende, en gran medida, nuestra imagen de la cosmoteología estoica antigua. La teología de Epicteto no supera, de manera significativa, los límites de la ortodoxia estoica. Su teísmo podría recurrir a los primeros ejemplos estoicos, y se considera que está sujeto a las mismas limitaciones o restricciones que lo separan de las formas personalistas del teísmo, que se pueden encontrar, por ejemplo, en la tradición cristiana. Las diferencias en tenor y énfasis

\footnotetext{
${ }^{62}$ Algra, "Epictetus and the stoic Theology," 46-47.

${ }^{63}$ Algra, "Epictetus and the stoic Theology," 47-48.
} 
entre Epicteto y los textos sobrevivientes de los estoicos de la Estoa antigua se deben, en cierta medida, a la personalidad de Epicteto, a su espíritu de piedad y a la inclinación socrática de su pensamiento ${ }^{64}$.

\section{LA CONCEPCIÓN DE DIOS Y LA PERSPECTIVA CÓSMICA}

Epicteto en su concepción de la divina providencia y la racionalidad sigue la tradición general de la filosofía estoica. Su carácter distintivo se extiende principalmente al entusiasmo con el que elogia la obediencia a Dios y el calor que infunde en sus expresiones de la preocupación por los seres humanos. Lo podemos ver en el sugerente pasaje 1.14.13-14: "Acordaos de no decir nunca que estáis solos, porque no lo estáis, sino que la divinidad está dentro y vuestro propio espíritu divino también." E insiste, como cualquier estoico, en la necesidad de acomodarnos a cada circunstancia externa dada por Dios. Pero cree que esa dura receta se basa en una asociación literal entre Dios y el sujeto individual ${ }^{65}$.

Epicteto pertenece a la tradición teológica estoica que comprende el panteísmo y el teísmo en una compleja amalgama, donde Dios se concibe como una fuerza física omnipresente encarnada en el fuego o aliento de fuego (pneuma) y el alma gobernante del mundo. Bajo la primera descripción, Dios (principio activo) se combina con la "materia" (principio pasivo) para formar el mundo y, de hecho, hace al mundo uno consigo mismo ${ }^{66}$. En este sentido panteísta, el mundo es Dios. El panteísmo se ha visto, a menudo, incompatible con una concepción teísta o personalista de Dios, pero los estoicos antiguos estaban tan comprometidos con el segundo como con el primero. La mente de Dios, afirmaron, tiene pensamientos e impulsos que difieren en alcance y poder más que en naturaleza de los propios

${ }^{64}$ Algra, "Epictetus and the stoic Theology," 54-55.

${ }^{65}$ LONG, Epictetus, 147.

${ }^{66}$ LONG, Epictetus, 161-162. En la cosmología estoica antigua la "materia" es una "substancia desprovista de cualidad"-un principio tan plástico que la causa divina puede moldear de la manera que desee. En la creación del mundo, Dios impone propiedades sobre los elementos que limitan los cuerpos complejos formados por ellos. El efecto de la teología distintiva de Epicteto es defender la providencia divina contra la evidencia de nuestra vulnerabilidad corporal, y enfatizar el don extraordinario de nuestra autonomía mental. 
de las mentes humanas; $y$, como hemos visto, propusieron que nuestras mentes sean partes integrantes o vástagos de Dios ${ }^{67}$.

Según Long ${ }^{68}$, Epicteto compartió las mismas preocupaciones de los antiguos estoicos, pero las contrarrestó enfatizando el teísmo sobre el panteísmo o, más en concreto, afirmando la presencia de Dios en toda la naturaleza pero sin identificar a Dios con el mundo. Quizás podemos llamar a Epicteto panenteísta (uno que cree en la omnipresencia de Dios); pero, sin embargo, su concepción de Dios será más comprensible si lo imaginamos como una mente universal.

Epicteto nunca se refiere, de manera explícita, al principio pasivo "materia", y cuando menciona "cuerpo" las connotaciones que atribuye a la palabra son negativas, como no se encuentran normalmente en el estoicismo. No dice nada sobre la identidad física de Dios como fuego o aliento ardiente o movimiento vibrante. Tres veces, en contextos relacionados con lo inevitable del cambio humano y la muerte, se refiere a la necesidad del mundo para la regeneración cíclica de sus constituyentes (2.1.18; 3.24.10; 4.1.100-106), y una vez abre una ventana a la doctrina estoica que piensa que el mundo terminará en una conflagración cósmica ${ }^{69}$, durante

${ }^{67}$ LONG, Epictetus, 147-148. Dios es el principio formativo de las piedras, las plantas, los animales y los seres humanos. El Dios estoico está encarnado en todo y es la causa de todo. Tal panteísmo hace difícil de entender cómo Dios puede estar presente de manera ejemplar en el alma humana. Además, si nuestras almas son "partes" de la mente de Dios, es difícil de entender cómo nosotros como individuos somos capaces de pensar por nosotros mismos y asumir responsabilidad para nuestras vidas.

${ }^{68}$ Long, Epictetus, 148. Kavin Rowe, On True Life, 48. Epicteto, de hecho, no diferencia entre Dios y el cosmos; “Todas las cosas están unidas como una” (1.14.1-10). El Artífice no es alguien que está "fuera" de su trabajo, sino que él es, en un sentido estricto, parte del mismo trabajo. Están unidos, entrelazados, en última instancia, en la misma realidad. Sin embargo, en la gramática epicteta Dios no es simplemente otra palabra para el mundo en su totalidad. Él nombra, en su lugar, un cierto carácter del cosmos, una dirección dentro de su unidad general.

${ }^{69}$ AlgrA, "Stoic Theology," 173. Según Crisipo, el cosmos en el acto de conflagración realmente no muere (por lo tanto, en cierto sentido, no se destruye realmente). La conflagración no es la muerte -en el sentido estricto de la separación del alma y el cuerpo-, del cosmos. Dios, el alma más bien, consume el cuerpo del cosmos solo para renovarlo convirtiéndolo nuevamente en la humedad primitiva. En un sentido relevante, entonces, el cosmos no se destruye, sino que vive para ser eterno. НADOT, La ciudadela interior, 249 y 150-151. Los estoicos defienden la tesis del eterno retorno. El mundo se repite eternamente porque 
la que Zeus se comunica consigo mismo sobre su recreación del próximo ciclo mundial (3.13.4).

Epicteto está más preocupado por la posibilidad de la formación y práctica moral que por los problemas de física, pues no los aborda en las conversaciones con sus discípulos. Además, conocer la última composición de la materia puede estar más allá del conocimiento humano, incluso aunque lo pudiéramos conocer se podría cuestionar el valor o la necesidad de tal conocimiento para la filosofía o la vida práctica. Como seres humanos necesitamos comprendernos a nosotros mismos, es decir, conocer que somos por naturaleza sociables y amantes de compañía (3.13.5). En el primer fragmento de los que se han conservado en otras fuentes, responde a sus alumnos a estas mismas preguntas. Habla de la Naturaleza (1.6.21 y 1.16.9) o de Zeus como si fuese Dios (como en 1.6.3 y 1.19.11). Epicteto tiene la seguridad de que los seres humanos están equipados para entender cómo este principio cósmico gobierna el mundo y cómo, en particular, el ha hecho a los seres humanos no solamente animales sociales sino también "ciudadanos del mundo" $(1.9 .1 ; 1.19 .13 ; 2.10 .3 ; 3.24 .11)^{70}$.

Epicteto pensaba que los principios generales de la cosmología teísta eran demostrables más allá de cualquier desafío y tendría buenas razones para no presentar a sus estudiantes ideas complejas y no demostrables sobre la estructura física del mundo y sobre la relación exacta de Dios con la materia. Los argumentos teológicos del diseño de la naturaleza, es decir,

el fuego racional que se despliega en el mundo está sometido a un movimiento perpetuo de diástole y sístole, la sucesión de los cuales engendra una serie de periodos idénticos, durante los que se repiten, de manera idéntica los mismos acontecimientos. El mundo nace del fuego original y vuelve al fuego original, con un comienzo y un final; pero su voluntad es siempre idéntica y solo puede repetir, por su acción continua, este mundo con este comienzo y este fin y todo el desarrollo de los acontecimientos que se sitúan entre ambos momentos.

${ }^{70}$ LoNG, Epictetus, 150 y 152. En numerosos pasajes Epicteto atribuye a Sócrates su propio tratamiento de la teología $(1.4 .24 ; 1.9 .1 ; 3.1 .19 ; 3.7 .36 ; 4.4 .21)$. El fragmento mencionado también se puede entender en el sentido de que, según la interpretación de Jenofonte, no se preocupaba sobre los elementos del mundo, sino que alcanza al conocimiento sobre la condición humana y las normas de la vida comunitaria. Aunque lo que Epicteto hace con la preocupación divina por los seres humanos y la teleología divina va mucho más allá de cualquier influencia socrática. Epicteto tenía sus propias razones para ser reticente a la física esotérica y al panteísmo, pero sabía que tenía también un precedente socrático para ignorar las preguntas sobre la composición última de la materia. 
el orden y la armonía que se perciben en el mundo natural, como lo respalda Epicteto (1.6.1-11; 1.14.1-6; 1.16.7-8; y 2.14.11/25-27), han sobrevivido durante mucho tiempo a la ciencia antigua, $\mathrm{y}$ han sido respaldados por personas que estaban en total desacuerdo con los pormenores de la física. Epicteto se centró en lo esencial y demostrable de la tradición estoica sobre la naturaleza -la providencia incondicional de Dios y la preocupación especial por los seres humanos ${ }^{71}$.

Epicteto reafirma que, según los filósofos estoicos, lo primero que debemos aprender es que Dios existe y que es providente con todo, por lo que no se muestra indiferente o impasible a nuestro modo de obrar, de pensar y de sentir (2.14.11). Este cuidado de Dios por nosotros o la presencia de dios en nosotros nos procura paz, serenidad y satisfacción (3.13.12-13).

Aunque Epicteto prácticamente no habla de los detalles físicos de la cosmología, se acercó estrechamente a aquellas partes de la tradición estoica antigua que se adaptaban a su interés dominante en el gobierno divino del mundo y sus implicaciones en los seres humanos. Nos enseña a aceptar las cosas que suceden tal y como son. Es importante que conozcamos el orden del universo, no para cambiarlo, sino para, que siendo las cosas como son y cómo es su naturaleza, tengamos nuestro parecer en armonía con los acontecimientos (1.12.15-17). El hombre honesto subordina su parecer al que todo lo gobierna e intenta seguir a los dioses en todas las cosas, pero al mismo tiempo mantiene el libre albedrío (1.12.7-9). La tarea del filósofo consiste en adaptar su propia voluntad a los acontecimientos que no dependen de nosotros sino de la razón universal (2.14.7.). Nuestra responsabilidad como individuos es únicamente sobre el área en la que somos capaces de ser autónomos, lo que depende de nosotros:-el propio uso de las impresiones mentales- (1.12.34). Todo lo demás es asunto de Dios; solo nos preocupa el hecho de que nos adaptemos a comprender su justificación dentro del sistema providencial del mundo ${ }^{72}$.

Cleantes en su celebrado Himno a Zeus alaba y ora al "Zeus omnipotente, el primer motor de toda la naturaleza". Se dirige a Zeus como el agente racional de todos los procesos naturales y como el padre que ha dado a los seres humanos la semejanza con él. Presenta a Zeus como

\footnotetext{
${ }^{71}$ LONG, Epictetus, 151.

${ }^{72}$ LoNG, Epictetus, 153.
} 
creador de la raza humana y comparte con ellos su capacidad para la inteligencia y la moral. Zeus representa a la humanidad y al mundo, en general, la encarnación y promulgación de la ley natural. Cleantes acredita la ley natural, también descrita como "razón universal", con dos aspectos, uno externo y otro interno. Externamente, se refiere al orden inevitable de los sucesos naturales -la salida del sol y las estructuras de los seres vivos-. Todo ello manifiesta racionalidad y orden, ajustándose a un patrón armonioso. Internamente, la ley natural o la razón universal se refieren al orden moral, común a lo divino y a lo humano. En este sentido moral, la comunidad de ley y razón es algo que las personas individuales tienen la capacidad para descubrir dentro de ellos mismos: en particular, están equipados para comprender su bien natural basado en la inteligencia y la cooperación en comparación con la competencia egoísta por la fama o las posesiones, y el placer sexual ${ }^{73}$.

Las personas tenemos que obrar de modo apropiado y ordenadamente de acuerdo con nuestra naturaleza racional para alcanzar nuestro objetivo $(1.6 .15 ; 3.1 .25)$. La fórmula favorita de Epicteto es mantener la propia libertad en armonía con la naturaleza (Manual 4). La persona puede centrar su interés en el propio albedrío y, lo puede modelar de modo, que sea acorde con la naturaleza (1.4.18). El vivir de acuerdo a la naturaleza se puede traducir también en seguir a los dioses $(1.12 .5 ; 1.12-7$ $8 ; 1.20 .15 ; 1.30 .4$ y 4.7.20) esa es la meta de la vida humana. En seguir a Dios reconocemos que él es el autor de nuestra naturaleza y, por lo tanto, seguir a Dios es vivir de acuerdo con la naturaleza (1.16.19) y en eso consiste la buena vida. No necesitamos a Dios, como alguien diferente de nosotros, para que nos diga lo que tenemos que hacer, sino que somos de la familia de Dios, de su misma naturaleza, por lo tanto, nuestro fin es vivir siguiendo a la divinidad.

Aunque somos poca cosa en comparación con el universo, en cuanto a la razón, no somos inferiores a los dioses (1.12.26.). "No soy eterno, sino un ser humano, una parte del universo, como una hora es una parte del día. Tengo que estar presente como la hora, y pasar, como la hora.” (2.5.13

${ }^{73}$ LoNG, Epictetus, 154. Existe una justificación tanto para el mal como para el bien porque la coexistencia de estos opuestos es una característica necesaria del orden cósmico. En este mundo estoico divinamente ordenado todo encaja como la combinación de concordancias y discordias en una sinfonía perfectamente compuesta y dirigida. 
y 25). Por medio de la razón comprendemos que Dios ha creado todo lo existente en el mundo. "Todas las criaturas han sido excluidas de comprender el gobierno del mundo, pero el animal racional tiene capacidades para reflexionar sobre todas las cosas: que él es una parte y que está bien que las partes cedan al todo.” (4.7.6-7). Todas las cosas están hechas por los dioses. Pero no son cosas fundamentales, ni son partes de la divinidad. Mientras que tú eres primordial, tu eres una chispa divina; tienes en ti mismo una parte de ella (2.8.10-11) y llevas a Dios dentro de ti mismo" (2.8.13).

Los fragmentos anteriores hablan de Dios de manera panteísta. En ellos Epicteto ofrece sus propias formulaciones de la relación parte/todo por la que los estoicos expresaban la relación del ser humano individual con el principio divino. Por un lado, somos simplemente episodios transitorios en la vida eterna del universo. Por otro lado, en virtud de nuestras almas, somos literalmente "partes" de Dios o del cosmos (2.10.3). La primera perspectiva nos invita a disminuir la importancia que damos a nuestra posición particular en el mundo; pero la segunda perspectiva nos eleva a la condición divina. Al presentar ambas perspectivas, Epicteto desafía a sus alumnos a descubrir lo que hace que las dos perspectivas sean consistentes. La respuesta es una actitud de indiferencia hacia nuestro cuerpo y nuestras desgracias, por un lado, y, por otro lado, una valoración de la racionalidad como la característica especial de la identidad de cada ser humano. Con esta estrategia, lo que hace Epicteto, es realzar la identidad humana al hacernos participes de la condición divina y participar en el cuidado divino del universo ${ }^{74}$.

\section{NUESTRO PARENTESCO CON DIOS Y LA PRESENCIA INTERIOR DE LA DIVINIDAD}

El objetivo principal de la teología de Epicteto consiste en irradiar luz sobre el autoconocimiento humano y la orientación moral. Él resume

${ }^{74}$ Long, Epictetus, 155-156. Algra, “Stoic Theology", 168. Se afirma con rotundidad que la racionalidad de dios -o, para el caso, la racionalidad del cosmos- no difiere en especie de la racionalidad humana, por lo que hasta cierto punto Dios puede verse como una "persona" con propósitos e intenciones. 
todo esto en uno de los discursos más comprimidos y poderosos (1.3.1-3): "Debemos captar con justeza el pensamiento, de que todos procedemos de la divinidad y que la divinidad es el padre de los dioses y de los hombres. Deberíamos estar orgullosos sabiéndonos hijos de Zeus. Pero, en realidad, no lo hacemos, pues en nuestro origen se mezclan dos cosas, de un lado, el cuerpo, común con los animales, y de otro la razón y el pensamiento, comunes con los dioses. Por una parte, estamos inclinados a un parentesco desdichado y mortal, y solamente unos pocos hacia el parentesco divino y bienaventurado."

Por nuestros cuerpos, nos parecemos a los otros animales, pero en virtud de nuestras almas, nos asemejamos a Dios. Hay cosas que tenemos en común con los animales: comer, beber, descansar y reproducirse, pero a nosotros se nos ha dado la facultad de compresión, y ya no nos basta con lo anterior, sino que debemos seguir nuestra naturaleza y disposición si queremos alcanzar nuestro objetivo (1.6.13-16). En otro lugar, Epicteto define al ser humano como "animal mortal capaz de servirse racionalmente de las representaciones" (3.1.25). Es esta segunda diferencia la que nos eleva sobre el resto de los animales. Epicteto no considera la mortalidad humana como una cosa mala, sino como parte constitutiva. Sin embargo, denigra, con frecuencia, nuestro aspecto corporal, a menudo llamando al cuerpo, cadáver, barro o tierra, y otras, usando diminutivos "pequeña carne" o "pequeño cuerpo" (2.19.27; 3.10.15; 3.22.41). No hay en la tradición de la filosofía estoica antigua un rechazo del cuerpo. Según la metafísica estoica, cada cosa que existe, incluyendo a Dios y el alma, es corporal. Pero Epicteto es tan reticente con esta doctrina como lo es con la relación física de Dios con el mundo. No es que Epicteto considere que la parte divina de nuestra naturaleza sea incorpórea, como Platón; téngase en cuenta que dos veces se refiere al pneuma como la substancia del alma (2.23.3; 3.3.22). Lo que Epicteto quiere resaltar es la dualidad en nuestra constitución humana que nos da la opción de decidir si debemos ser como Dios (identificándonos con nuestras almas) o simplemente animales (identificándonos con nuestros cuerpos).

Epicteto recomienda a sus discípulos elevar la valoración de sí mismos identificándose exclusivamente con sus almas o con el parentesco divino (3.1; 1.9.13-14). En (1.9.10-11) insiste en nuestro parentesco con los dioses, aunque estemos sujetos a ciertas ataduras del cuerpo. Está de acuerdo con Sócrates al considerar el cuerpo como un enredo, pero tal 
molestia no es razón para detestarlo y optar por el suicidio. Es desacertado morir para escapar de las propias circunstancias materiales. La actitud apropiada para el propio cuerpo es tratarlo sin importancia (1.9.16-17). Para actualizar nuestro parentesco divino, necesitamos tratar nuestras almas como el lugar exclusivo de nuestra identidad humana. Ese proyecto requiere considerar nuestros cuerpos como instrumentales para nuestra vida y diferentes de nuestro ser esencial, pero esas no son razones para descuidar el cuerpo ${ }^{75}$.

Minimizando la importancia del cuerpo, Epicteto mantiene su foco sobre la facultad racional como la portadora esencial de la identidad humana $^{76}$. Recordemos sus afirmaciones en el primer discurso del libro 1.1.14. Allí relata a sus alumnos cuatro cosas: primero, que la racionalidad es una facultad reflexiva general sobre el juicio; segundo, que esta facultad, que nos capacita para hacer un uso correcto de nuestras impresiones mentales, es nuestra más preciosa dotación; tercero, que Dios nos ha dado autonomía completa sobre esta facultad; y cuatro, que Dios habría extendido tal autonomía a nuestro cuerpo.

Hay tres aspectos reseñables de la perspectiva teológica de Epicteto: Dios ha dotado a los seres humanos con la capacidad de autonomía, Dios está dentro de nosotros, y la relación de Dios con la mente o el alma, como

${ }^{75}$ Long, Epictetus, 159. Kavin Rowe, On True Life, 47. Epicteto recuerda a sus discípulos que son "hijos de Dios" (1.3.2;1.9.6) "Dios es el Padre de todos los humanos" (1.3.1; 3.22.82; 3.24.15-16 et passim). Pero somos hijos de Dios por nuestra capacidad de razonar, eso nos asegura nuestro parentesco con Dios (1.1.4). Al decir "eres un fragmento de Dios", quiero decir que "tienes una parte de él en ti mismo" (2.8.11), y esa parte, por supuesto, es tu razón. El hecho de que Zeus haya dado a cada uno de nosotros nuestro propio daimon, Epicteto se refiere, a nuestra razón como una forma de describir el carácter esencialmente divino (1.14.14). De hecho, Epicteto argumenta que, en virtud de nuestra racionalidad, no somos "inferiores a los dioses"; de hecho, somos sus iguales (1.12.26-7; 1.14.11). Es por eso que incluso como individuos, Epicteto afirma, nunca estamos separados de Dios: (1.14.1314). Estamos, entonces, “entrelazados con Dios a través de la razón” (1.9.5).

${ }^{76}$ LONG, Epictetus, 161. Epicteto destaca la capacidad del alma para la autonomía en un grado que no tiene precedentes en la tradición estoica. Lo hace con diferentes pasos: el contraste entre el cuerpo y el alma, la identificación del alma con la persona individual y la asignación a la mente de una capacidad invencible de autodeterminación. En el pasaje (3.24.2 y 62) nos dice que la divinidad hizo a todos los seres humanos para ser felices, lo que incluye salud, estabilidad y tranquilidad, por eso no conviene ser desdichado por causa de nadie. Zeus ha hecho lo mejor que pudo a los seres humanos y, de haber sido posible, también nos habría dado cuerpos invulnerables. 
algo distinto del cuerpo. Estos tres puntos están íntimamente relacionados, y Epicteto interpreta la tradición estoica con los ojos puestos en Platón o en el Sócrates de Platón ${ }^{77}$.

La divinidad estoica tradicionalmente se identifica con el destino, y el ser humano debe estar sometido de manera absoluta a él, pues todo aparece determinado. Los primeros estoicos, especialmente Crisipo, hicieron todo lo posible para mostrar como el destino divino era compatible con la acción y la responsabilidad humana, pero igualmente convencidos de que nada, incluidas las decisiones y elecciones de la mente, estaban libres de determinación, lo que no aparece bien explicado.

En este punto hemos de decir que Epicteto tiene una concepción diferente pues insiste en la proairesis que se traduce por "voluntad", "elección racional". Para Epictetus, nuestra proairesis es nuestro verdadero ser y, a diferencia de nuestro cuerpo, nunca puede estar limitado por lo externo (1.17.21-23). A menudo, Epicteto dice que tú eres tu proairesis (3.1.40), algo que ningún tirano ni el mismo Zeus puede restringir (1.1.23-24; 1.18.17; 1.19.8). Nada ajeno al libre albedrío puede poner impedimentos o perjudicar al albedrío (3.19.2.). Decir que tú eres tu proairesis no es muy diferente de decir que eres tu voluntad, pero la proairesis solo juega algunos de los roles de voluntad, está también relacionada con la libertad y la responsabilidad. En términos generales, tu proairesis es tu decisión racional, la personalidad moral que dirige tus decisiones racionales, sobre cómo es conveniente $\operatorname{actuar}^{78}$.

Epicteto se muestra reticente sobre el modo de entender el destino, pues dado que no hay nada superior al libre albedrío y a él todo le está subordinado (2.1.1), se podría sugerir que ha abandonado la doctrina estoica del determinismo universal, pues tampoco encontramos textos en los que intente compaginar la autonomía personal con el destino. En cambio, nos pide que aceptemos, como un artículo de fe, que nada externo a la mente de una persona, ni el mismo Dios, en cuanto agente supremo de

${ }^{77}$ Long, Epictetus, 156. GiLl, "The School," 47. Además de que Epicteto tiene una concepción socrática de Dios, también se puede ver a Epicteto como el exponente de una versión exigente del estoicismo, que desestima las ventajas en la vida ética y que favorece el ideal austero cínico en lugar de la práctica de la virtud dentro de un estilo de vida más convencional.

${ }^{78}$ SoRABJI, "Epictetus on proairesis," 88. 
los sucesos del mundo, puede ejercer la coacción sobre los deseos, las elecciones o las decisiones propias ${ }^{79}$.

Desde el principio, los filósofos estoicos han tratado la afinidad entre Dios y los seres humanos como una 'asociación', en la que el alma humana es un "retoño" o "parte" de la mente divina. El texto de Crisipo (DL VII, 87-88): "Nuestras propias naturalezas son partes de la naturaleza del universo. Por lo tanto, vivir de acuerdo con la naturaleza es el fin de la vida, es decir, de acuerdo con la naturaleza de uno mismo y la naturaleza del universo, sin participar en actividades que la ley universal prohíba, lo cual es la razón correcta que lo impregna todo y es idéntico a Zeus, quien dirige la disposición de la realidad. Y cuando el principio de cada acción está en concordancia entre el espíritu divino (daimon) de cada persona y la voluntad del director del universo, precisamente esta es la virtud de la felicidad del ser humano y su buen flujo de la vida".

En este memorable pasaje Crisipo se hace eco del Himno a Zeus de Cleantes identificando a Dios con el autor universal y la ley natural, y tratándonos a nosotros como sus partes. Él va más allá de las palabras poéticas de Cleantes cuando describe la felicidad y la virtud no solo como obediencia a la ley divina y la recta razón sino también como una relación concordante entre el espíritu divino de cada persona y la voluntad de Dios en la capacidad de Dios como administrador del mundo.

Dios ha dado a cada persona una parte de sí mismo. Epicteto caracteriza este don divino como la razón o la proairesis, es decir, frente a la razón universal y voluntad universal divina que dirige todo lo que acontece en el universo, cada persona tiene una razón individual, que es una emanación, una parte de la razón universal. Pero tiene que haber una cierta armonía entre esta razón o voluntad universal y la razón o libertad particular. Zeus es el agente causal universal, pero no puede restringir la voluntad de la persona, es decir, la voluntad individual, por su propia naturaleza, no está sujeta a coerción, por lo que dejamos la pregunta de la causalidad o del destino completamente abierta. Sin embargo, el sabio es-

${ }^{79}$ LOng, Epictetus, 162. Algra, "Stoic Theology,"175. La breve oración al final del Manual (53): "Condúceme Zeus, y tú, Destino," aunque se dirige a Zeus (y el destino), de hecho, puede considerarse como que se dirige a uno mismo. Representa una forma de meditación, de decir al propio ser racional que Zeus es el que guía, y que cada uno tendrá que seguir, de todos modos, los decretos del destino. 
toico o el estoico perfecto hace coincidir su razón o voluntad personal completamente con la razón universal de Zeus, y, dado que esa volición es en sí misma parte de Zeus, Epicteto no deja espacio para una libertad que sea realmente independiente de la causación divina, de este modo, se equilibra la razón particular y la razón universal.

Esta misma idea se encuentra en el número 1 del Manual donde se diferencia entre las cosas que dependen de nosotros y las que no dependen de nosotros o, dicho de otro modo, entre la causalidad interior (nuestra facultad de elección, nuestra libertad moral) y la causalidad exterior (el destino y le curso universal de la naturaleza). Nosotros podemos desear lo que depende de nosotros, el bien moral, y huir de lo que depende de nosotros el mal moral, y así ejercemos nuestra libertad, pero al mismo tiempo, tenemos que someternos a lo que no depende de nosotros, lo cual supone seguir el destino o la razón universal de la naturaleza ${ }^{80}$. Pero al mismo tiempo, es necesario que en muchos momentos nuestra voluntad se identifique con la voluntad divina, que ha querido tal acontecimiento para mantener la serenidad. Eso aparece muy bien expresado en el número 8 del Manual: "No pretendas que los sucesos ocurran como tú quieres, sino que quiere los sucesos que suceden y vivirás sereno.” No depende de nosotros que ciertas circunstancias no nos ayuden o sean un obstáculo para nuestra acción. Debo aceptar eso con serenidad (3.18.1-3). Pero sí depende de nosotros utilizar con solicitud, con habilidad, las circunstancias de nuestra acción tal como las ha querido el destino. Epicteto utiliza la comparación del juego de dados (2.5.3-5), no depende de nosotros que salga un dado u otro, pero sí depende de nosotros usar cuidadosa y hábilmente lo que salga, es decir, las circunstancias de nuestra actuación.

No es fácil justificar qué es el espíritu divino (daimon) de cada persona. La palabra daimon puede ser equivalente a Dios en el sentido pleno, pero en griego se aplica más frecuentemente a un semidiós, algo intermedio entre el ser humano y el divino. Adicionalmente, daimon a menudo significa el destino de una persona o fortuna, como en las palabras eudaimon significa feliz y kakodaimon significa infeliz. Lo que no aclara el texto

${ }^{80}$ HAdOT, La ciudadela interior, 320. El único valor absoluto es la intención moral. Es lo único que depende enteramente de nosotros. No cuenta el resultado, que no depende de nosotros, sino del Destino; cuenta la intención que tenemos al intentar alcanzar este resultado. Este tema se encuentra en (2.16.15) 
de Crisipo es qué relación exacta hay entre la persona y su daimon. No ayuda traducir daimon por "espíritu guardián", como se hace a veces, porque la misma cuestión aparece: es el daimon interno a la persona o es más bien un ángel guardián. Long ${ }^{81}$ sugiere que Crisipo no tenía interés en ángeles guardianes, para él el daimon es lo que cada persona comparte con la razón divina. El daimon de Crisipo sería la facultad racional o lo que dirige a la persona. Corresponde a las personas individuales hacer que su propio daimon esté de acuerdo con Dios: las personas serán virtuosas si consiguen que su daimon esté de acuerdo con la razón divina. Pero no debemos olvidar que el estar dotado con la facultad divina de la razón, no se sigue que lo que nos dicta nuestro razonamiento sea bueno.

Veamos los textos en los que Epicteto se refiere al daimon: "Dios ha dado a cada persona un daimon como protector personal... Acordaos de no decir nunca que estáis solos, porque no lo estáis, sino que la divinidad está dentro y vuestro daimon también ${ }^{82}$." (1.14.11-14). Aquí Epicteto habla como si el daimon fuera un alter ego o al menos un superego ${ }^{83}$. Pero ahora, en un contexto donde destaca la autonomía completa de la persona sobre la moral, a diferencia de los valores externos afirma: "Yo ya sé a quién he de agradar, a quién subordinarme, a quién obedecer: a la divinidad, y después de ella a mí mismo. Dios me ha confiado a mí mismo y ha subordinado mi voluntad solo a mí, dándome normas para su uso correcto." (4.12.11-12). Finalmente, otro texto que hemos repetido: "Llevas a la divinidad de un lado a otro, y tú pobre cosa, no lo sabes. ¿Te parece que hablo de un dios externo hecho de oro o plata? Lo llevas dentro de ti mismo y no te das cuenta que estás salpicándolo con pensamientos impuros, con acciones sucias (2.8.12-13)."

${ }^{81}$ LONG, Epictetus, 164.

82 Rodríguez Moreno, Inmaculada, “Demonología estoica,” en Habis 30 (1999)," 183. Epicteto solo considera existentes a estos démones como seres buenos, los cuales no viven fuera, sino dentro de los hombres. La razón humana, parte divina, (1.14.6 y 2.8.11), es identificada con el genio o demon bueno que acompaña a todo individuo desde su nacimiento en calidad de protector, de acuerdo con la creencia tradicional griega.

${ }^{83}$ Rodríguez Moreno, “Demonología estoica,”182. La teología de Epicteto se caracteriza por la presencia de un dios providente o Zeus, quien a su vez proporciona al individuo un guardián o genio custodio, siempre alerta, tanto de día como de noche (1.14.12-14). No obstante, debemos obedecer al demon y, al mismo tiempo, confiarle todo (4.4.39-40), ya que se trata de la emanación de Zeus mismo, de cuyos designios él es mensajero. 
En (1.14.11-13) dice que Zeus ha puesto un vigía en cada uno de nosotros, encomendándonos a cada uno su cuidado. Este vigía es nuestro daimon guardián. Después viene una sección difícil de entender: "Cuando cierres tu puerta y oscurezca en tu interior, recuerda no decir nunca que estás solo. Pues no estás solo, sino que dios y tu daimon están en tu interior”. Parece que Epicteto está hablando de cerrar las puertas del yo, afirmando que el daimon no solo está dentro del edificio, sino dentro del mismo yo. En este sentido, en el fragmento (2.8.11) señala que el hombre es diferente de todo lo demás del universo pues es un fragmento de Dios. Según Rist ${ }^{84}$, lo que quería decir Epicteto no es que seamos partes de dios, sino que hay alguna parte de dios en nosotros, cada uno posee una parte de la racionalidad de Dios. Es como decir que hay un elemento específico del hombre, lo que le identifica y constituye, que podía ser el nous, y eso es precisamente la parte divina. Pero a diferencia de Posidonio, en ningún momento, de modo específico, dice que el nous sea el daimon, es decir, evita la identificación del daimon con el nous. A pesar de ello, piensa en él como una parte del ser humano, algo que lleva consigo, como algo que ha de mantenerse puro (2.8.13 y 21).

Epicteto está cerca de los pensamientos citados de Crisipo, pero con tres diferencias. Primero, el daimon de Epicteto es con toda seguridad, como no lo es en Crisipo, el ideal racional o la conciencia. Segundo, situando a Dios dentro de la persona, Epicteto da una carga emocional muy vigorosa a la doctrina que, por razón de nuestras almas en su propio funcionamiento, no solamente somos partes de Dios, sino que actuamos con Dios o como Dios quiere que actuemos. Tercero, el lenguaje de Epicteto tiene un compromiso apasionado que está ausente del sobrio Crisipo. El concepto de daimon de Epicteto tiene mucho en común con lo que nosotros llamamos conciencia ${ }^{85}$. Lo que nos retrotrae una vez más al pensamiento de Sócrates, quien se veía poseído por un daimon que le aconsejaba y orientaba sobre los hechos más significativos de su vida, en calidad de espíritu protector o la voz de la conciencia misma, producto de una experiencia personal e inspirador de un auxilio oportuno, en una palabra, la Providencia divina ${ }^{86}$.

${ }^{84}$ Rist, M. J., La filosofía estoica, Ariel, Barcelona 2017, 210-211.

${ }^{85}$ LONG, Epictetus, 166.

${ }^{86}$ LONG, Epictetus, 167. Sócrates era reconocido por confiar en su daimon o signo divino, que él consideraba una voz infalible de la conciencia. Epicteto se refiere a esto (3.1.19) 
En sus comentarios sobre la presencia del guardián divino dentro de la persona, Epicteto está de acuerdo con Séneca y Marco Aurelio. Donde quizás él difiere de ellos es en la estricta coincidencia que postula entre Dios dentro de o el daimon y la conciencia, la voz de la razón recta que está disponible para todos porque es, al mismo tiempo, razón como tal y equivalente a Dios. Aunque Epicteto a veces habla como si la presencia o la disponibilidad de esta voz pluraliza la persona, o hace a la persona distinta de su daimon, debemos considerar el lenguaje como metáfora, o mejor, como un modo de articular la idea que al escuchar y obedecer la propia conciencia, uno está, al mismo tiempo, de acuerdo con la divinidad que dirige el mundo ${ }^{87}$.

\section{CONCLUSIÓN}

No se pueden negar las numerosas semejanzas verbales que existen entre Epicteto y los escritos del Nuevo Testamento, pero no hay apoyos fundados para postular una influencia directa de uno en el otro. Epicteto ha sido mal entendido, por hacer tantas referencias a la teología, y ha sido leído a la luz del cristianismo. No tenemos razones para pensar que los cristianos o los escritos cristianos hayan influido directamente en él. Creemos que es una cuestión que sigue abierta, ya que algunas de sus concepciones religiosas son cercanas al cristianismo, en cambio, hay también otros aspectos que no son fáciles de conciliar con él, por eso es un tema que sigue abierto al debate ${ }^{88}$.

Según Keimpe Algra ${ }^{89}$, hay una distinción clara entre la teología de Epicteto y la tradición cristiana. Es cierto que, desde el principio, los cristianos han mostrado interés en los textos de Epicteto, como se puede ver

cuando dice que Sócrates se apegó a su deber militar bajo la autoridad de Dios (Apol. 28 e). Difícilmente podemos dudar de que al extender el daimon a cada persona, Epicteto tuviera también en mente esta conciencia socrática.

${ }^{87}$ LONG, Epictetus, 166.

${ }^{88}$ SPAnNeut, "Epiktet," 627-628. Aquí se estudia la obra de Epicteto y resalta como la han utilizado los escritores cristianos, en concreto, los padres de la Iglesia. Aunque también presenta algunas descripciones del posible uso que Epicteto hace del mensaje cristiano evangélico.

${ }^{89}$ Algra, "Epictetus and the stoic Theology," 51-52. 
en las versiones cristianizadas del Manual. Sin embargo, hay una diferencia crucial entre cómo se contempla la relación entre el hombre y Dios en el teísmo cristiano, por un lado, y tal como se concibe en lo que se podría llamar el cuasi-teísmo epictetano, por otro. Según el estoicismo, Dios le ha dado al hombre los medios para cumplir con todas sus obligaciones; estas capacidades están en nuestro poder y tenemos una responsabilidad (1.6.3743). Por lo tanto, el ser humano puede, por estos poderes y dones, conocer a Dios a la perfección, amarlo, obedecerlo, complacerlo, curarse de todos sus vicios, adquirir todas las virtudes, hacerse santo, y así ser compañero de Dios. De este modo, en el sistema filosófico de Epicteto no hay espacio para la gracia como un acto libre de Dios, ni para cualquier otra intervención divina específica en la vida de los individuos. Según Epicteto, nuestra felicidad, nuestra virtud, nuestra actitud racional depende de nosotros, aunque haya sido Dios, al comienzo, el que nos haya concedido esas facultades.

Aquí se pone de manifiesto la diferencia con el Dios cristiano, pues en el estoicismo el cuidado providencial de Dios consiste en que el mundo está estructurado de la manera más racional y perfecta posible, y lo que nosotros tenemos que hacer es conocerlo y amoldarnos a esa estructura. La actitud de Dios hacia el mundo y hacia nosotros se caracteriza por la racionalidad, no hay lugar a emociones y, por lo tanto, no hay espacio para el amor y la misericordia. Por eso, aunque haya ciertas semejanzas, necesitamos mostrar las diferencias. La más importante es la identificación típica estoica entre Dios y la perfección racional. No hay brecha entre un estoico sabio y Dios porque el ser humano, en virtud de su ser racional, es obediente a Dios de conformidad con la ley y voluntad divina. Ya hemos reiterado cómo Epicteto habla de "Dios dentro de nosotros". A veces distingue el guardián divino o daimon en el ser humano, de Dios como tal, pero nunca podemos pensar en un Dios estoico trascendente en el sentido cristiano de la primera persona de la Trinidad $^{90}$, a pesar de que en muchas ocasiones, se dirige a este Dios como padre (1.3.1-2; 1.6.40; 1.9.7; 3.11.5; 3.22.82; 3.24.3; 3.24,15-16 et passim).

En el cristianismo, al contrario, Dios aparece como una voluntad personal que gobierna nuestras vidas y se preocupa de cada uno de nosotros.

${ }^{90}$ Long, Epictetus, 145. El dios estoico es inmanente e idéntico con la racionalidad perfecta. Epicteto sigue su tradición en tomar el carácter general de Dios y sus obras para ser completamente accesible a la comprensión humana. 
Hemos de reconocer también que en Epicteto aparecen rasgos esenciales cristianos, por ejemplo, en (3.24.) de manera reiterada nos recuerda que "la divinidad hizo a todos los hombres para ser felices, para vivir con equilibrio." Zeus se ocupa de los hombres para que sean semejantes a él, es decir, felices, pues de otra manera mal gobernado estaría el mundo (3.24.19). Nos impulsa también a ser "amigo de la divinidad" (3.24.60) y nos repite que la divinidad nos ha dispuesto para que seamos dichosos. Dios es feliz y virtuoso y se nos presenta como un ejemplo a seguir. Queda pues patente, que Dios es alguien próximo, una persona que se preocupa de todos nosotros y nos acompaña en nuestro camino, la providencia de Dios es cercanía y cuidado. La originalidad de Epicteto estriba en que este lenguaje, ser hijos de Dios o la paternidad de Dios sobre nosotros, no se puede tomar como una metáfora, sino que Dios es realmente nuestro padre y actúa como tal, y, por lo tanto, tenemos el derecho de llamarnos y ser "hijos de Dios"

Como hemos visto y podemos concluir ahora, en la teología no hay una ruptura sustancial entre Epicteto y el estoicismo ortodoxo, pero tenemos que tener en cuenta el énfasis o el estilo personal de Epicteto. También hemos de reseñar que los matices teístas personalistas son mucho más prominentes en las Disertaciones que los panteístas o perspectivas politeístas. Por supuesto, no podemos descartar la posibilidad de que Epicteto simplemente era mucho más piadoso que cualquiera de los otros estoicos y que un lenguaje teísta representa la forma que él mismo pensó y vivió el Dios estoico, como han afirmado algunos investigadores ${ }^{92}$.

${ }^{91}$ Kavin Rowe, True Life, 46-47. Epicteto en (1.12.1-3) resume cuatro puntos de vista erróneos en relación a Dios que se deben rechazar. Primero, la noción de que la divinidad no existe; segundo, que existe, pero es indiferente y no es providente; tercero, que existe y es providente, pero solo se preocupa de las cosas grandes y celestes, y se despreocupa de las cosas terrenas; y, cuarto, que ejerce la providencia para las cosas terrenales y humanas, pero solo de manera general, y no se preocupa de cada individuo. En contraste, con estos cuatro puntos de vista erróneos, nos dice Epicteto que deberíamos ponernos de lado de Odiseo y Sócrates, esos sabios que sabían que nada se oculta a Dios. Por lo tanto, el quinto punto de vista correcto es afirmar que Dios existe y su providencia abarca no solamente a las cosas celestiales importantes, sino también a las cosas terrenales y preocupaciones humanas, y que Dios se preocupa de los seres humanos de forma individual. Dios se relaciona con cada uno de nosotros, diría Epicteto. Después de todo, somos hijos de Dios.

${ }^{92}$ Algra, "Epictetus and the stoic Theology," 52-53. Ierodiakonou, "The Philosopher," 60. La autora nos recuerda que muchos estudiosos modernos han indicado que en, 
La posición que A. Long adopta sobre la preferencia de Epicteto por el lenguaje teísta en lugar del panteísta es ampliamente compartida por muchos eruditos. Lo cual no quiere decir que Epicteto haya abandonado formalmente el panteísmo en favor de un teísmo estricto. Él no aborda ese problema directamente. Sin embargo, si le preguntáramos qué cree sobre Dios y cómo quiere que sus discípulos piensen en Dios, la respuesta de las Disertaciones parece ser la concepción "personalista" que hemos defendido ${ }^{93}$. En esto Epicteto difiere notablemente de Marco Aurelio $^{94}$, quien rara vez describe a Dios de esta manera, pero constantemente personifica "la naturaleza" o "el mundo" o "el universo", viéndose a sí mismo como "una parte del todo", más que como una "parte de Dios".

Aunque es cierto que en Epicteto se puede encontrar una interpretación teísta y panteísta de su teología estoica, tenemos que considerar, como nos recuerda Brancovitch ${ }^{95}$, que hay pasajes que son irreductibles a una concepción panteísta (1.6.40-42;2.23.42;3.5.7-10;4.10.14-17). Estos cuatro pasajes aluden a la idea -recurrente en la obra de Epicteto- de que debemos estar agradecidos a los dioses y no culparlos por los acontecimientos que tienen lugar en el universo, pues nos han dado facultades

algunos aspectos, Epicteto va más allá de la ortodoxia estándar. La teología de Epicteto se caracteriza por un tono personalista cálido que no tiene paralelo con los escritos de los primeros estoicos.

${ }^{93}$ Braicovich, Rodrigo Sebastián, "Teísmo y Panteísmo en la teología de Epicteto: ¿es el lenguaje personalista una estrategia pedagógica?," Estud. filos. Universidad de Antioquia 43 (2011), 180. El lenguaje marcadamente personalista de numerosos pasajes de las Disertaciones, sumado a los diálogos y las plegarías dirigidas a Zeus que encontramos recurrentemente en sus páginas ofrecen apoyo a dicho consenso, en tanto parecen evidenciar un distanciamiento decisivo respecto de la concepción naturalista e inmanente de la divinidad defendida por el estoicismo antiguo.

${ }^{94}$ LONG, Epictetus, 178. Marco Aurelio constantemente invoca la perspectiva cósmica y raramente se refiere a Dios en singular por su nombre, prefiere hablar de la naturaleza o del todo, y su concepción del mundo es bastante unitaria. Marco Aurelio, como "una parte del todo" está destinado, como todo lo demás, para ser reabsorbido en el flujo de los elementos, que es la forma en que la naturaleza preserva el mundo de la manera más beneficiosa. Epicteto, al contrario, raramente habla de esta perspectiva cosmológica. Long considera que, de todos los estoicos, Marco Aurelio es quien más se acerca a un panteísmo estricto. Véase también Rutherford, R., The Meditations of Marcus Aurelius. A Study, Oxford University Press, New York, 228-229.

${ }^{95}$ Braicovich, "Teísmo y Panteísmo," 184-185 y 187. 
para afrontar los obstáculos y las adversidades. La idea de gratitud hacia los dioses ${ }^{96} \mathrm{y}$, por otra parte, la exigencia de agradar a los dioses no parece que se puedan conjugar con un sistema estrictamente panteísta y materialista como el defendido por el estoicismo antiguo. Por lo tanto, todo esto nos lleva a seguir defendiendo la existencia de elementos personalistas en Epicteto, es decir, hay muchos pasajes en las Disertaciones que se resisten a una interpretación panteísta: 1.9.7; 1.12.6-8; 1.30.1;2.8.18-19;3.5.8;3.13.6; 3.24.14-16; 4.1.109; 4.12.11.

Otro aspecto recurrente en las Disertaciones es la oración, esa reverencia y agradecimiento a Dios por todo lo creado (1.16.16-21). En esta oración nos invita a ser agradecidos y respetuosos con la providencia, en vez de quejarnos ${ }^{97}$. "Si fuéramos sensatos ¿habríamos de hacer alguna otra cosa, tanto en público como en privado, más que alabar a la divinidad y bendecirla y enumerar sus favores? Grande es la divinidad, que nos proporcionó estos medios para que trabajemos la tierra. Grande es la divinidad, porque nos dio manos, porque nos dio vientre [...] Sería necesario cantar esto en cada ocasión, elevar el himno más grande y más divino porque nos concedió la capacidad de comprenderlo y de seguir el camino de la razón. Nuestra tarea debe ser cantar el himno de la divinidad e invitar a todos a participar del mismo canto." En la oración aparecen expresiones piadosas dirigidas de manera delicada a la divinidad. Dios estimula nuestro canto, alabanza, oración y devoción. Dios no se identifica simplemente con un conjunto de juicios razonados sobre el mundo. En (3.26.2829) se reconoce que Dios no se despreocupa de los asuntos humanos, sino que, por el contrario, nos guía y acompaña. Por lo que la tarea del hombre es agradecer a la divinidad lo que nos ha concedido en la vida: "Y es que llegué cuando a él le pareció y de nuevo me voy cuando le parece" mientras tanto nuestra tarea es cantar a la divinidad por contemplar con admiración las obras y comprender su gobierno (3.5.10; 1.6.19-22 y

${ }^{96}$ 4.10.16: "Te agradezco que me engendraras, te agradezco lo que me diste. Todo era tuyo, tú me lo diste." Dios es el dador, por eso debemos ser agradecidos, pero al mismo tiempo, saber que al final todo retorna a él, lo que hemos recibido es como un préstamo. Nada nos pertenece ni nuestra vida ni la de nuestros amigos y familiares, al final todo hay que devolverlo (Manual, 11). Y como lo hemos recibido todo de Dios, incluso nuestro mismo ser, no hay lugar para quejarnos ni lamentarnos al que nos lo ha dado (4.1.100-103).

${ }^{97}$ El mismo pensamiento se repite en el capítulo 31 del Manual: "Nunca harás reproches a los dioses ni les reclamarás el despreocuparse de ti." 
2.16.41-42.47). El canto y agradecimiento a la divinidad (4.5.35) debe ser el quehacer de los seres humanos ${ }^{98}$.

Hemos visto que Epicteto atribuye al ser divino, al igual que las grandes religiones monoteístas, la extraordinaria providencia y la bondad. Para Epicteto la divinidad es el creador del mejor de todos los mundos posibles. La conformidad a Dios y la imitación de Dios son expresiones que utiliza en la caracterización de la virtud humana, Dios es el paradigma de las virtudes que los seres humanos están llamados a alcanzar (1.12.7; 1.25.3-6; 2.14.12-13). No obstante, hay que decir que en el estoicismo no existe nada más allá del mundo ni de los principios materiales, ni hay ningún Dios trascendente. Al mismo tiempo, está la inmanencia estoica, y cuando se aplica a la teología necesariamente debe conducir a un panteísmo. Si bien es posible hablar de dioses, e incluso de un dios supremo, como lo hace Epicteto, este dios no se opone al mundo, sino que es un componente inmanente de él.

Epicteto habla frecuentemente de un Dios personal (1.12.4-6;1.13); hemos de decir que a pesar de este lenguaje, el estoicismo no tenía un Dios completamente personal. Para Epicteto Dios es naturaleza (1.4.18 y 3.24.94), una parte del ser humano (1.14.6), y últimamente parte del todo (2.5.25-26;3.13.16), por lo que el punto de vista de Epicteto es ciertamente panteísta. Según esto, no es fácil poner en duda la visión panteísta del estoicismo, pero como nos dice Bonhöffer, en los detalles sigue siendo un punto oscuro y ambiguo. Es imposible explicar los diferentes aspectos del Dios estoico con una noción libre de contradicción. El panteísmo de Epicteto no prohíbe hablar de una visión personal de los dioses. Aunque es evidente que habla de Dios en sentido panteísta, al mismo tiempo utiliza expresiones que, hablando estrictamente, comprenden a Dios como un ser personal. Y aquí creo que se encuentra la novedad y originalidad de Epicteto, en presentar una concepción del gobierno o providencia de Dios personalista, muy cercana a la cristiana, pues Dios se preocupa y cuida de todos sus hijos en todos los momentos y de manera continua ${ }^{99}$.

${ }^{98}$ Spanneut, "Epicktet," 614.

${ }^{99}$ Rodriguez Moreno, "Demonología estoica," 183-184. El pensamiento teológico de Epicteto presenta un tono más religioso, más solemne, que le lleva a personificar a la divinidad (3.1.37). Él defiende la existencia de Dios, o dioses, como un buen rey, un buen padre $(1.6 .40 ; 1.3 .1)$ un amigo (3.24.60), que se ocupa de todos nosotros, sus hijos, en todos 
Otra diferencia importante es que, para Epicteto y para todos los estoicos, nuestras almas son literalmente vástagos de Dios, partes que él mismo ha asignado para que sean el alma o la identidad de cada persona. Como racionalidad cósmica, Dios también existe fuera del alma de cada individuo porque él es el principio estructural de todo el universo; y Epicteto, como otros estoicos, utiliza un lenguaje que puede sugerir que Dios es distinto de su creación. Pero esto no puede tomarse literalmente. El Dios estoico es naturaleza, extendiéndose a todo, y mientras Epicteto, a diferencia de los primeros estoicos, no presta atención en explicar cómo Dios puede estar físicamente presente en todos los lugares, no difiere de sus predecesores sobre la identidad de Dios con el orden natural de las cosas. El punto de vista estoico sobre Dios es de este mundo en el sentido de que no hay un dominio sobrenatural para el cual deberíamos estar preparándonos en esta vida, no hay un "fin de los días" cuando las vidas serán juzgadas. La vida que tenemos ahora es lo que requiere toda nuestra atención; el único castigo para quienes descuidan los principios del estoicismo, dice Epicteto, es permanecer tal como están, perturbados y descontentos desde el punto de vista emocional (1.12.21-22;3.11.1-3) ${ }^{100}$.

Sin embargo, en otro sentido, en la perspectiva estoica sobre Dios puede verse una invitación a rechazar los valores mundanos y a asimilarnos completamente a la racionalidad divina. Porque la naturaleza de Dios es racionalidad perfecta, y esta misma condición es adecuada, al menos teoréticamente, a los seres humanos, es decir, la doctrina estoica de que Dios o Zeus son sin comparación mucho más poderosos de lo que puede ser cualquier otra persona, aunque no fueran superior en virtud y felicidad a lo que el ser humano podría, en principio, alcanzar. Epicteto nunca respalda del todo este pensamiento (que era peor que la herejía para el cristianismo), pero la asimilación a lo divino que defiende (2.14.13) da a las personas un estatus potencial que elimina virtualmente la diferencia cualitativa entre el ideal humano y el divino. Lejos de estar contagiados por el pecado original, los seres humanos están equipados innatamente por Dios para perfeccionarse a sí mismos por sus propios

los momentos y de una manera continua $(3.24 .3 ; 1.3 .3$; 1.9 .6$)$. El hombre, por su espíritu, está más cercano a Él, en lo que a la jerarquía de seres se refiere, ya que es poseedor de un alma que se encuentra ligada a Dios como parte y fragmento de su ser.

${ }^{100}$ LONG, Epictetus, 145-146. 
esfuerzos. No hay necesidad de la gracia divina ni de redención o sacrifi$\operatorname{cio}^{101}$.

Tanto Epicteto como Séneca consideran que la filosofía estoica es la cura para lo que aflige a los seres humanos. Para ambos la filosofía es un arte de vivir (1.15.2). En este sentido, en las cartas, se puede encontrar una relación entre el lenguaje teológico de Séneca y Epicteto. Epicteto está menos preocupado que Séneca por los estragos del destino. Epicteto dice una vez que "el paradigma de todos los males que nos sobrevienen es el miedo a la muerte" (3.26.38), pero Epicteto está mucho menos preocupado existencialmente por el problema de la mortalidad humana que Séneca. Epicteto cree, como Séneca, que la muerte nos vuelve polvo (4.7.15), pero no ve ninguna razón para detenerse en nuestro fin. Aunque ambos piensan profundamente en la Providencia, la confianza de Epicteto en Dios es mayor. Donde Séneca advierte, de modo constante, a Lucilio contra las cosas buenas de la vida, Epicteto aconseja a sus alumnos que canten himnos. Donde Séneca ve las trampas de la fortuna, Epicteto discierne los dones de Dios. Donde Séneca dice: “CCuidado!” Epicteto dice: “Confía en Dios". Podríamos resumir diciendo, a pesar de la complejidad, que el mundo que habitamos no es tan aterrador para Epicteto como lo es para Séneca ${ }^{102}$.

En Epicteto encontramos un tono de optimismo y confianza que no aparece en el estoicismo romano, y, en algunos rasgos, se acerca mucho al pensamiento cristiano, aunque todo depende de la lectura que hagamos, pues no podemos olvidar que algunas de estas características se deben a la influencia socrática y cínica. Lo que supone volver un tanto a los orígenes de la Estoa antigua, que se aleja de muchos de sus planteamientos cosmológicos y físicos, pues se centra mucho más en los aspectos éticos. En este sentido se entiende la visión personalista de Dios y su cercanía, pues Epicteto más enfáticamente que otro estoico habla del principio divino del mundo como persona, por lo que se aleja del sentido impersonal y material de la divinidad tradicional estoica.

${ }^{101}$ LONG, Epictetus, 146-147.

102 Kavin Rowe, On True Life, 64. 